\title{
A Workflow to Define, Map and Name a Carbonatite- or Alkaline Igneous-Associated REE-HFSE Mineral System: A Case Study from SW Germany
}

\author{
Graham J. Banks ${ }^{1, *}$, Benjamin F. Walter ${ }^{2} \mathbb{D}$, Michael A.W. Marks ${ }^{2}$ and Pete R. Siegfried ${ }^{3}$ \\ 1 Geological Survey of Denmark and Greenland, DK-1350 Copenhagen, Denmark \\ 2 Department of Geoscience, University of Tuebingen, Wilhelmstrasse 56, D-72074 Tuebingen, Germany; \\ benjamin.walter@uni-tuebingen.de (B.F.W.); michael.marks@uni-tuebingen.de (M.A.W.M.) \\ 3 GeoAfrica Prospecting Services, P.O. Box 24218, Windhoek, Namibia; geoafrica@yahoo.com \\ * Correspondence: gb@geus.dk; Tel.: +45-9133-3897
}

Received: 4 December 2018; Accepted: 24 January 2019; Published: 9 February 2019

\begin{abstract}
Security of supply of "hi-tech" raw materials (including the rare earth elements (REE) and some high-field-strength elements (HFSEs)) is a concern for the European Union. Exploration and research projects mostly focus on deposit- to outcrop-scale description of carbonatite- and alkaline igneous-associated REE-HFSE mineralization. The REE-HFSE mineral system concept and approach are at a nascent stage, so developed further here. However, before applying the mineral system approach to a chosen REE-HFSE metallogenic province its mineral system extent first needs defining and mapping. This shifts a mineral system project's foundation from the mineral system concept to $a$ province's mineral system extent. The mapped extent is required to investigate systematically the pathways and potential trap locations along which the REE-HFSE mass may be distributed. A workflow is presented to standardize the 4-D definition of a REE-HFSE mineral system at province-scale: (a) Identify and hierarchically organize a mineral system's genetically related sub-divisions and deposits, (b) map its known and possible maximum extents, (c) name it, (d) discern its size (known mineral endowment), and (e) assess the favorability of the critical components to prioritize further investigations. The workflow is designed to generate process-based perspective and improve predictive targeting effectiveness along under-evaluated plays of any mineral system, for the future risking, comparing and ranking of REE-HFSE provinces and plays.
\end{abstract}

Keywords: REE; HFSE; mineral system; mapping; extent; favourability; predictive targeting; endowment; facies association; play; exploration

\section{Introduction and Aims}

\subsection{Introduction to Critical Raw Materials and the REE-HFSE}

The global plan to decarbonize energy and transport systems is leading to rising demand for a range of natural resources [1]. Some of these resources are the rare earth elements (the lanthanides, scandium and yttrium) and the high-field-strength elements (elements with $\geq 3$ ionic charge and ionic radii versus ionic charge number $(\mathrm{Z} / \mathrm{r})$ of $>2$, e.g., niobium, hafnium, and tantalum). These metals were designated by the European Commission [2,3] as "critical raw materials" due to their high economic importance and high supply risk. This contribution focuses on the $\mathrm{REE}, \mathrm{Nb}, \mathrm{Ta}, \mathrm{Hf}$, and $\mathrm{Zr}$ (REE-HFSE). These commodities are mainly associated with carbonatite and alkaline igneous rocks and their weathered products, e.g., References $[1,4,5]$.

Much REE-HFSE research and exploration has focused on deposit- to outcrop-scale carbonatite and alkaline igneous bodies identified by: Geological survey and research work [6]; geochemical 
or geophysical pathfinder signatures [7]; or serendipitously, e.g., during uranium prospecting [7]. Knowledge of the location controls of these metals remains limited compared to knowledge about base and precious metal deposits [5]. Many of the $>500$ known carbonatite occurrences [8] remain under evaluated. The result is recent REE mining from only a few deposits related to carbonatite and alkaline igneous bodies [1,9], e.g., the Bayan Obo Fe-REE deposit in China [10,11]; the Mountain Pass carbonatite-hosted REE deposit in the USA [12]; the Mount Weld carbonatite-associated lateritic REE and $\mathrm{Nb}$-Ta deposits in Australia (e.g., Reference [13]) and the Araxa carbonatite-associated, lateritic $\mathrm{Nb}$ deposit in Brazil [14]. Other REE mines are of ion-adsorption clay deposits and monazitexenotime-bearing placer deposits (e.g., Reference [9]). For details of REE and carbonatite-related data, uses, occurrences, and mines refer to References [1,5,15-19].

\subsection{Aims and Audience}

As most REE-HFSE-centric exploration and research projects tend to focus efforts on the depositto outcrop-scale they neglect to place occurrences within their wider context, where significant undiscovered potential may exist. To help address this knowledge gap we present a method and workflow for defining, mapping and naming any REE-HFSE mineral system associated with carbonatite and alkaline igneous rocks. The objective is to 4-D summarise the current knowledge status of the selected mineral system. It is designed so that geoscientists, economists, and strategists of research, industry, geological survey, and governmental organizations can easily, quickly, and cheaply understand any REE-HFSE mineral system's extent. It is for use at any exploration or research project phase, although it will generate optimal efficiency and value if used to select district- or deposit-scale project locations. It is also able to provide context for upside potential around known occurrences, prospects, and mines in already-selected areas. The workflow can also be adapted to define the mineral system extents of other commodities.

As REE-HFSE recycling is unlikely to meet increasing demand [20,21], appraisal and mining [22] of known occurrences and discovery of new deposits are likely required to secure their supply. Closer collaboration between industry, research, and government policymaking will be essential to improve exploration efficiency and geological chance of success, and lower geological risks. The overall aim of this workflow is to assist industry, research, financial, and government policy stakeholders to more effectively visualize, assess and target under-evaluated mineral systems at province-scale. This includes prioritizing data acquisition budget and discerning geological uncertainties. Moreover, it is designed to facilitate discussion and understanding between these stakeholder groups, and to improve decision quality across the REE-HFSE sector. The Southwest Germany, Tentative, Variscan-Miocene Carbonatite REE-HFSE mineral system case study is used to demonstrate the proposed workflow (Section 3), because of its "greenfield" maturity, numerous REE-HFSE occurrences, historic niobium mine, substantial volume of subsurface data, and lack of mineral system approach.

\subsection{The Mineral System Concept for Mineral Deposit Formation}

The mineral system concept (better considered as a mineralizing system concept) has been used for $>20$ years to conceptualize the overlap of necessary, i.e., "critical" [23], geological processes and elements to form and preserve mineral deposits [24] of various commodities [23,25-29]. In this document, we use and recommend the term "mineral system critical components" instead of mineral system critical processes and elements, because REE-HFSE commodities are often termed critical elements in REE-HFSE research parlance. The mineral system concept is the scientific framework needed to meet the challenges of spatial prediction for new mineral resources [30]. This concept envisages a mineral deposit as a relatively small, resultant expression of large-scale mineral system processes, i.e., a foci of energy and mass transfer. A mineral deposit is thus the rare, yet predictable, outcome of the geological evolution of active terranes [23]. A mineralizing system extracts commodity at low concentration from large volumes of rock and focuses them at higher concentrations in smaller volumes of rock (e.g., Reference [30]). Initially, large-scale geodynamic processes concentrate commodities into province- or district-scale "source" regions. The commodities 
are later re-mobilized through progressively narrowing scales by advective mass flux of magmas or hydrothermal fluids [31]. Localized permeable zones or crustal pathways (e.g., faults, shear zones, and lithologic units) enable large quantities of commodity-transporting magmas or fluids to focus during short timeframes, into environments where chemical, physical or thermal gradients cause commodity deposition [31]. Commodities can be further concentrated, re-transported, and re-deposited (or dispersed) by subsequent weathering, metamorphism, or erosion.

The mineralizing system for the formation of REE-HFSE deposits associated with carbonatite and alkaline igneous rocks can be summarized as follows [11,13,14,19,32-36] and references therein. Low-degree partial melting of a pre-enriched ("fertilized"), sub-lithospheric, mantle source (e.g., by metasomatism due to earlier subduction) produces "primary" magmas that are relatively enriched in incompatible REE-HFSEs compared to higher-degree partial melts of a similar or depleted mantle source. These "primary" magmas ascend through the lithosphere, exploiting focused zones of transient structural permeability. During ascent, extensive magmatic differentiation by fractional crystallization or liquid immiscibility concentrates incompatible elements in the melt. At upper crustal levels, these elements partition into mineral species that can host high concentrations of REE-HFSEs. Fluids relating to subsequent metamorphism can also lead to further enrichment. Exhumation, weathering and erosion of magmatic, hydrothermal or metamorphosed mineralization in tropical and subtropical climates can lead to further chemical or physical enrichment of the REE-HFSEs.

\subsection{The Mineral System Approaches and Their Applications to REE-HFSE Investigations}

Effective evaluation and ranking of mineral occurrences in low data areas requires an approach built around regional-scale, fluid flux-centric processes. This is to replace the traditional, empirical comparison of geoscience data to mineral deposit "types" in well-explored, data-rich terranes. Ore-forming systems show a diversity of chemical processes yet a narrower range of physical processes [23]. Understanding the latter is the key to predictive targeting of mineral deposit locations [23]. This is the mineral system approach. It has been applied recognize, and focus upon, the drivers of mineralisation, e.g., geodynamic setting, crustal architecture, magma/fluid flow drivers and pathways and mineral deposition mechanisms [37]. A mineral system's signatures typically extend far beyond the mineral deposit, and therefore enable more effective targeting for mineral deposits than the traditional "needle in a haystack" approach [38]. Hence, the mineral system approach should be used as an organizing framework to link mineralization research and mineral systems science to exploration targeting (Figure 1; [39]). It should be used to create targeting vectors that reduce the overall cost of target selection and increase the efficiency of exploration, appraisal and research [38].

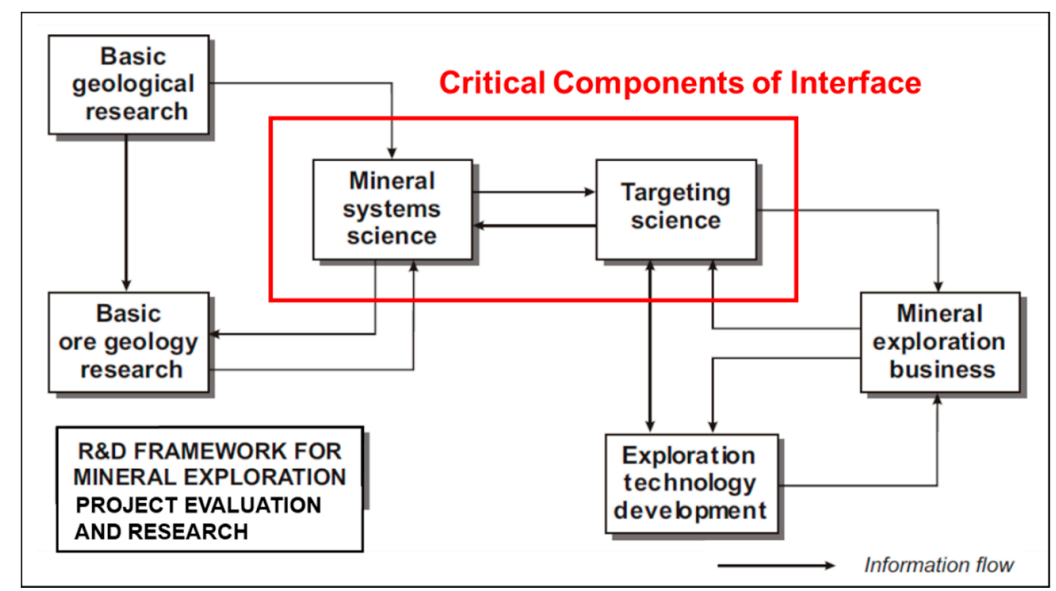

Figure 1. The role of mineral systems science and targeting science for optimizing the interface between Research and Industry. Modified and reproduced with permission from Hronsky, J.M.A., Optimising the Interface between Economic Geology Research and the Industry, AMIRA International's Exploration Managers Conference, 2010 [39]. 
The mineral system approach has been applied across a range of institutions and commodities. This has generated a spectrum of published formulations and approaches ("descriptive", "empirical", "conceptual", "contextual", and "probabilistic") to perceive a mineralization system and select a commodity's critical components. Additionally, the approach has been used for a variety of purposes: to develop process-based conceptual models of ore systems (e.g., Reference [25]); to create flexible probabilistic structures for conducting quantitative risk analysis [40] and to describe essential ingredients of mineral systems for prospectivity mapping (e.g., References [24,29]). A systematic organization of the various mineral system approaches is required, based on scales of application and volume of hard data.

Most carbonatite- and alkaline igneous-associated REE-HFSE literature only catalogues and lists characteristics of mineral occurrences and their host rocks, mostly at deposit scale, e.g., References [5, $8,16-18,41,42]$ and references therein. However, some recent publications have considered parts of a mineral system approach, albeit along different formulations. A "descriptive" approach was used by [42] to classify 14 REE deposit types in Australia's carbonatites, (per)alkaline rocks, and associated regolith. This was done by expanding the original six mineral system "ingredients" [43] for ore body formation into seven, "Mineral-system features" [42] (by including geological setting, age, relative timing of mineralization, and preservation). Those authors also grouped Australia's REE deposit types into Regolith, Basinal, Metamorphic and Magmatic "Mineral-system association categories" [42]. A "contextual" formulation by Reference [44] tentatively identified and partly translated five mineral system critical processes for REE deposits into some mappable targeting criteria. An "empirical" mineral system approach was created for New Zealand's intrusion-related REE mineralization [45,46] that spans craton-scale energy source to ore shoot-scale trapping of REE minerals. Those authors expanded the six-component mineral system of [24] into 12 "critical processes", and translated them into some regional-, outcrop- and thin section-scale mappable criteria. Their resultant geochemistry and lithology base maps provide a foundation for regional-scale REE mineral prospectivity mapping. A "descriptive" mineral system approach for a REE mineral system framework by [47] displays text summaries and sketches, but with limited information about how to map critical components.

To summarize, some initial steps towards identifying and sketching some carbonatite- and alkaline igneous-associated REE-HFSE mineral system components and considerations have been published. However, none include the preceding task of a standardized mineral system definition. Section 2 presents our proposed workflow to define, map, name and then hypothesize the potentially undiscovered mineralization districts of any REE-HFSE mineral system. Before then, we first clarify various mineral system terms from this contribution and published literature.

- A mineral system: Proposed in this paper as the entire set of naturally occurring, genetically related, mineralizations (ore deposits, mineral deposits and mineral occurences) that originated from one commodity-yielding provenance.

- Mineral System Definition: Proposed in this paper as the second stage of a holistic prospect evaluation process, and used to describe and map the extent and size (known mineral endowment) of any REE-HFSE mineral system in a standardized way.

- The mineral system concept: the overlap of geological processes and elements "critical" to form and preserve mineral deposits (e.g., References [23,24]). A more appropriate name suggested here is the mineralizing system concept.

- The mineral system approach: Any of a range of published organizing frameworks that have been applied to understand mineralization by focusing on the drivers of the overall mineral system (e.g., References $[24,25,29,40])$. A more appropriate name suggested here is the mineralizing system approach.

- Mineral system critical components: Proposed by this paper for the REE-HFSE mineral system components that must overlap to form and preserve mineral deposits. It is preferred to critical elements and processes [23], because REE-HFSE commodities are often termed critical elements in REE-HFSE research. 
- "Mineral-system association categories" [42]: A phrase synonymous with our proposed facies associations, that was used by Reference [42] to group Australia's REE deposit types.

- Play: Proposed in this paper as a group of geologically-related mineral occurrences within a chronostratigraphically bound unit.

- Play Analysis: Proposed in this paper as quantitative evaluation of plays based on geological uncertainties and risks.

\section{The Proposed Mineral System Definition and Workflow for Defining A Carbonatite or Alkaline Igneous-Associated REE-HFSE Mineral System}

\subsection{The Proposed Mineral System Definition}

Before commencing a carbonatite- or alkaline igneous-associated REE-HFSE mineral system analysis we recommend that the project is sub-divided into five, sequential, targeting stages of a holistic prospect evaluation process (adapted from Reference [48]): (a) Province Framework, (b) Mineral System Definition, (c) Play Analysis, (d) Prospectivity Mapping, and (e) Prospect Maturation. This division into stages is necessary because mineral system project objectives and targeting criteria differ at each of these five stages. Such sub-division makes it easy to visualize, compartmentalize and manage a project.

One carbonatite- or alkaline igneous-associated REE-HFSE mineral system is defined here as the entire set of naturally occurring and genetically related mineralizations (ore deposits, mineral deposits and mineral occurrences) that originated from one commodity-yielding provenance (adapted from Reference [49]). It extends from the active/once active provenance of sub-lithospheric mantle that yielded that mineral system's commodity "load" to all the resultant REE-HFSE occurrences distributed by magmatic, metamorphic, weathering and basinal processes. One system therefore encapsulates the geologic components critical for mineralization to exist, regardless of economics (adapted from References [50,51]), with emphasis on chronostratigraphic relationships between genetically linked occurrences. Using a tree geometry analogy, one mineral system has a sub-lithospheric mantle provenance root network, a magmatic-hydrothermal trunk that focused REE-HFSE-transporting magmas and fluids into the upper crust (vertical charge), and district- to ore shoot-scale migration pathway branches through, and atop, the upper crust (horizontal charge). Each REE-HFSE occurrence is akin to one fruit in one mineral system branch. Some mineral system branches may no longer exist due to the province's climatic history and erosion network. This highlights the preceding need for a Province Framework summary of the host region's geologic evolution. Hence, a mineral system spans the REE-HFSE provenance yield, magmatic/fluid charge pathways and the range of REE-HFSE-concentrating settings throughout the province. To hypothesize the spatial distribution of a metallogenic province's possible, undiscovered mineral endowment, the known mineral system 'tree' needs to be already mapped.

The Mineral System Definition stage is based upon geological processes. The objectives are to: (a) Define, map, and name any carbonatite or alkaline igneous-associated REE-HFSE mineral system at province scale, (b) determine the spatial and temporal distribution of the system's critical components, (c) genetically link REE-HFSE occurrences to each other and to their provenance, and (d) apply a contextual mineral system approach to evaluate the boundaries and uncertainties within which undiscovered plays and prospects may occur (modified from Reference [52]). It is a province-scale screening technique, so does not calculate any resource volumetric value, i.e., no detailed economic considerations. Economic estimations and investigations of district- then deposit-scale system processes and data, e.g., magma chamber magmatic-hydrothermal processes, are conducted at the subsequent, more-detailed, Play Analysis and Prospect Maturation stages.

Mineral System Definition is designed to encourage explorers and researchers to consider, identify and quantify the full range of possible mineralized plays and their constituent prospects across the entire province (adapted from Reference [51]) and under sediment cover. Questions it should stimulate include: "How long could this mineral system extend along the geodynamic evolution cycle? What are all the environments in which the commodity may have accumulated? Which play types and plays 
could be most enriched in the commodity? Which are most probable? Which could yield the largest tonnage? Would primary host mineral grains have been altered to secondary mineral grains of more favorable geometallurgy? Where may they have been re-transported and re-deposited?" Such enquiry should also eliminate unlikely hypotheses early in the project, so that data acquisition budget is only allocated towards the most prospective commodity migration pathways and plays.

Mineral System Definition can be conducted regardless of the amount of available data-knowledge. A low volume of data is not a hindrance, because data-knowledge gaps indicate how to best allocate data acquisition budget. In addition, the resultant uncertainties should be documented to inform decision-makers. The mineral system maps should be iterated when new data and interpretations arise, to capture new ideas, and adjust geological uncertainties and project strategy.

\subsection{The Proposed Mineral System Definition Workflow}

The workflow below and in Table 1 is a step-by-step guide to conduct the Mineral System Definition stage of a REE-HFSE project. Applying it will provide the user with a robust foundation to subsequently: (a) Gain geological processes-based perspective to explore for mineral resources, (b) predictively determine the most favorable mineral system branches to target/research, (c) probabilistically risk prospects during portfolio building, (d) have analogues for other, less-defined, mineral systems, and (e) compare and rank REE-HFSE mineral systems globally. It draws from the geological processes-based workflow to define any petroleum system in 4-D [49,53], and applies the mindset to hypothesize commodity migration from a system's initial source zone to all resultant accumulations, which has been economically successful standard practice for petroleum exploration for decades. This process-based petroleum system mindset has already been adapted by some mineral industry workers, e.g., References $[24,40,54,55]$. We have applied this mineral system definition workflow to the Southwest Germany part of the Central European Volcanic Province (Section 3).

(1) Task 1. Organise and Summarise All Province Framework Stage Data and Knowledge

All available data-knowledge about the host province's 4-D evolution and mineralizationincluding all historic exploration and production data-needs to be summarized and organized geospatially. This will include a province-scale geological setting and evolution summary (tectonic, structural, magmatic, metamorphic, hydrothermal, climatic, erosional and sedimentological). This helps contextualize and predict the timings, pathways, locations and preservation potential of the pervading mineral system. There is no minimum data to commence mineral system definition; documentation of the geological uncertainties will incorporate the data-knowledge availability.

(2) Task 2. State the Mineral System's Critical Components and the Project's Investigation Products

The four critical components we currently recommend for province-scale carbonatite- or alkaline igneous-associated REE-HFSE evaluations are fertility, whole-lithosphere configuration, transient geodynamics, and exhumation-preservation (modified from Reference [23]). Our research into the critical components at district and deposit-scales is ongoing, for example trapping and priming for further REE-HFSE enrichment. These critical components must have occurred in the correct order, and overlapped, in time and space (Figure 2) for a chance of mantle-derived REE-HFSE deposits being at/near surface today. A mineral system only exists where all the critical components are known to have overlapped. In addition, a mineral system may exist where there is encouraging to favorable probability of them overlapping. Evaluating these four components is valuable to (a) distil a targeting model down to fundamental parameters [24] and, (b) enable multiplicative, probability-based risking $[40,51,54]$ (and following standard petroleum industry best practice) for a province to have generated and preserved a mineral deposit. The critical components will be different at district and deposit scales, and in the different facies associations, so will require differing mappable criteria, e.g., Reference [37]. For example, lithospheric-scale strike slip fault systems would be included on 
province-scale mineral system maps whereas magma chamber roof zone outcrops would be detailed on deposit-scale maps.

Table 1. A workflow to define any carbonatite- or alkaline igneous-associated REE-HFSE mineral system at province scale (adapted from Reference [49]).

\begin{tabular}{|c|c|}
\hline Workflow Sequence & Workflow Tasks \\
\hline 1 & Organise and summarise all Province Framework stage data and knowledge. \\
\hline 2 & State the mineral system's critical components and the project's investigation products: \\
\hline 2.1 & State the mineral system's critical components. \\
\hline 2.2 & List the investigation products. \\
\hline 3 & Identify the mineral system: \\
\hline 3.1 & Find mineralisation. \\
\hline 3.2 & Determine the links within the mineral system: \\
\hline 3.2 .1 & Link and group genetically related occurrences. \\
\hline 3.2 .2 & Identify the source using occurrences-provenance correlations. \\
\hline 3.2 .3 & Locate the general area of the provenance. \\
\hline 4 & Hierarchically organise the mineral system's sub-divisions: \\
\hline 4.1 & Facies associations and enrichment vectors. \\
\hline 4.2 & Play types. \\
\hline 4.3 & Plays. \\
\hline 4.4 & Mineralisation types and host lithologies. \\
\hline 5 & Estimate the known mineral endowment of the mineral system: \\
\hline 5.1 & Resource volumes. \\
\hline 5.2 & Yield-mineralisation efficiency. \\
\hline 6 & Name the mineral system. \\
\hline 7 & Map the mineral system's known extent: \\
\hline 7.1 & Geographic extent. \\
\hline 7.2 & Stratigraphic extent. \\
\hline 7.3 & Temporal extent: \\
\hline 7.3 .1 & Critical moment. \\
\hline 7.3 .2 & Preservation time. \\
\hline 8 & Summarise the mineral system's favourability for undiscovered mineral endowment. \\
\hline 8.1 & List the potential play types, plays and mineralisation occurrences. \\
\hline 8.2 & List and compare appropriate analogues. \\
\hline 8.3 & Summarise the favourability of the four critical components of that facies association. \\
\hline 8.4 & Translate the critical components into mappable, targeting criteria and their proxies. \\
\hline 8.5 & Map the mineral system's maximum possible extent. \\
\hline
\end{tabular}

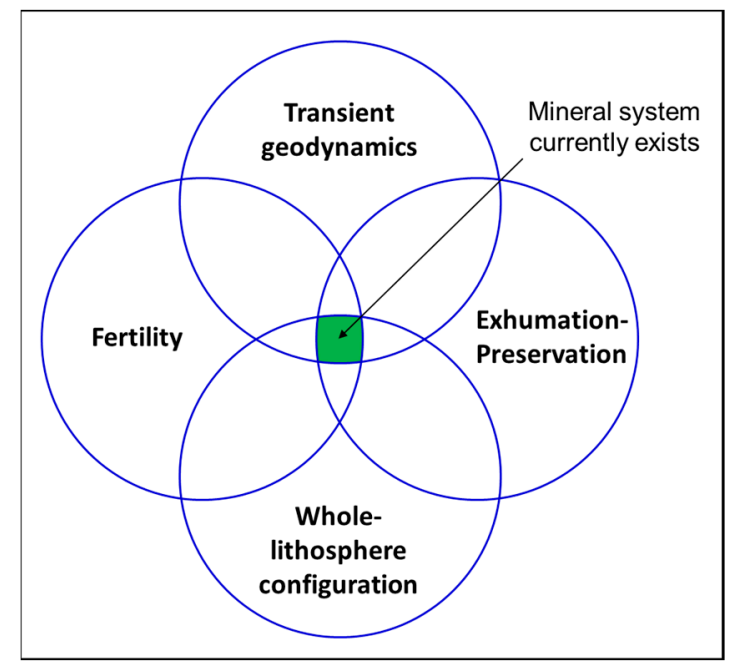

Figure 2. The four, province-scale, critical components necessary for a mineral system to have occurred and exist today. Modified from Reference [23] with permission from McCuaig, T.C. and Hronsky, J.M.A, The Mineral System Concept: The Key to Exploration Targeting, in Building Exploration Capability for the 21st Century, published by Society of Economic Geologists Inc., Littleton, CO, USA 2014. 
The following investigation products should be generated to summarize a mineral system in 4-D, to visualize areas for focus and identify potential mineralized plays:

- Correlations between mineralized occurrences.

- Correlations between mineralized occurrences and their commodity provenance.

- Table of produced and unrecovered mineral resources, to calculate the known mineral endowment (size) of the mineral system.

- Yield-accumulation efficiency.

- Map of the mineral system's geographic extent.

- Cross section of the mineral system's stratigraphic extent.

- Mineral system events chart showing the mineral system's temporal extent.

- Mineral system preservation history chart.

(3) Task 3. Identify the Mineral System

Before a REE-HFSE mineral system can be examined, demonstration that it exists requires at least one REE-HFSE mineralization that is geochemically anomalous in the context of the local lithologies, i.e., significantly above the region's surface baseline concentration (average bulk continental crust has $125 \mathrm{ppm}$ total REE [56]). This would be evidence that mineral system processes elevated the concentrations of the commodity [57], and could be a historic mine, ore deposit, mineralized outcrop, or mineralization observation in a drill core. Next, the genetic relationships between near-surface REE-HFSE occurrences need to be formalized by establishing petrological, mineral chemical, isotopic, and geochronological correlations, and integrating them with mapped crustal structures. This enables: (a) Mapping the known mineral system extent, (b) a framework to incorporate future discoveries, (c) mapping mineralized plays and mineralization episodes within that mineral system's duration. Subsequently, genetic relationships between the near-surface commodity occurrences and their sub-lithospheric provenance region need to be formalized. Mineralogical, geochemical, isotopic, or geochronological signatures are used to map the spatial extent of the provenance, to then infer where overlying districts may be underexplored/unknown. Petrological studies of near-surface occurrences help infer redox conditions, temperature, and pressure of the commodity provenance during commodity expulsion, e.g., Reference [58]. Geological, geophysical, and structural maps are integrated to correlate mineral occurrences and mantle provenance to lithospheric-scale REE-HFSE conduit structures.

\section{(4) Task 4. Hierarchically Organize the Mineral System's Sub-Divisions}

Mapping, modelling and quantifying the space-time span of a mineral system-from mantle expulsion period to the most distal deposit location-is improved by organizing a mineral system "tree" into a hierarchy of exploration targeting sub-divisions (Figure 3). This has already commenced to some extent in a small section of the mineral system literature. For example, Reference [25] split uranium mineral systems into: (a) Magmatic-related, (b) metamorphic-related, and (c) basin and surface-related, "families of mineralizing systems", with each family containing, "deposit styles". In contrast, Reference [42] classified the REE mineral system concept into four, "Mineral-system associations" containing numerous "Deposit types" [42]. The latter is a mix of depositional environments, depositional processes, deposit types and rock names (Figure 4). To standardize mineral system sub-divisions and visualize their relationships we recommend a scale-based hierarchy of mineral system sub-divisions that aligns with the Linnaean classification scheme [59] and the petroleum system divisions [60] and their logic. This will also allow easy extrapolation into other commodity mineral systems. Figure 3 displays the hierarchy of sub-divisions we recommend for any mineral system whilst Figure 4 exhibits how carbonatite- and alkaline igneous rock-associated REE "deposit types" [42] can be more effectively divided. Figure 5 demonstrates in cross-section the hierarchy of a mineral system's sub-divisions, and how deposits and prospects link to form plays. Figure 6 uses the Mount Weld Carbonatite Complex and the Ponton Creek Complex (Australia) to demonstrate how to place deposits 
and prospects within the proposed mineral system hierarchy, and summarize the causes of economic success or failure.

- A mineral system

- Its facies associations (regional deposition/trapping environments)

- Their play types (regional deposition/trapping processes)

- Their plays (chronostratigraphically-bound mineralised units)

- Their mineral occurrence types (resource, deposits and showings categorised into one or more deposit/trap types)

- Their host lithology types.

Figure 3. Scale-based hierarchy recommended for mineral system sub-divisions.

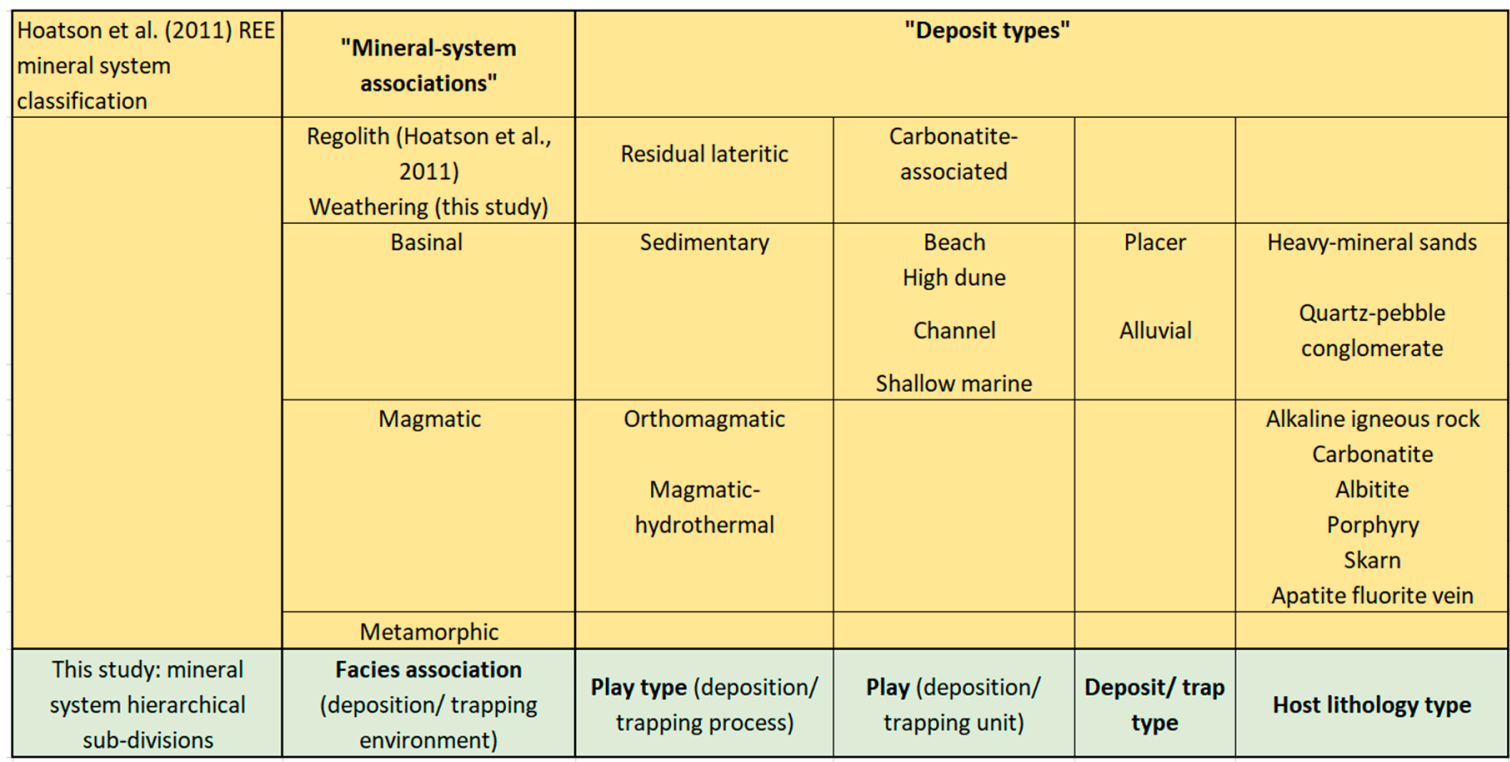

Figure 4. Categorising the mineral system classification of Australia's possible carbonatite- and alkaline igneous rock-associated REE deposit types (listed by Reference [42]) into a scale-based hierarchy of mineral system sub-divisions.

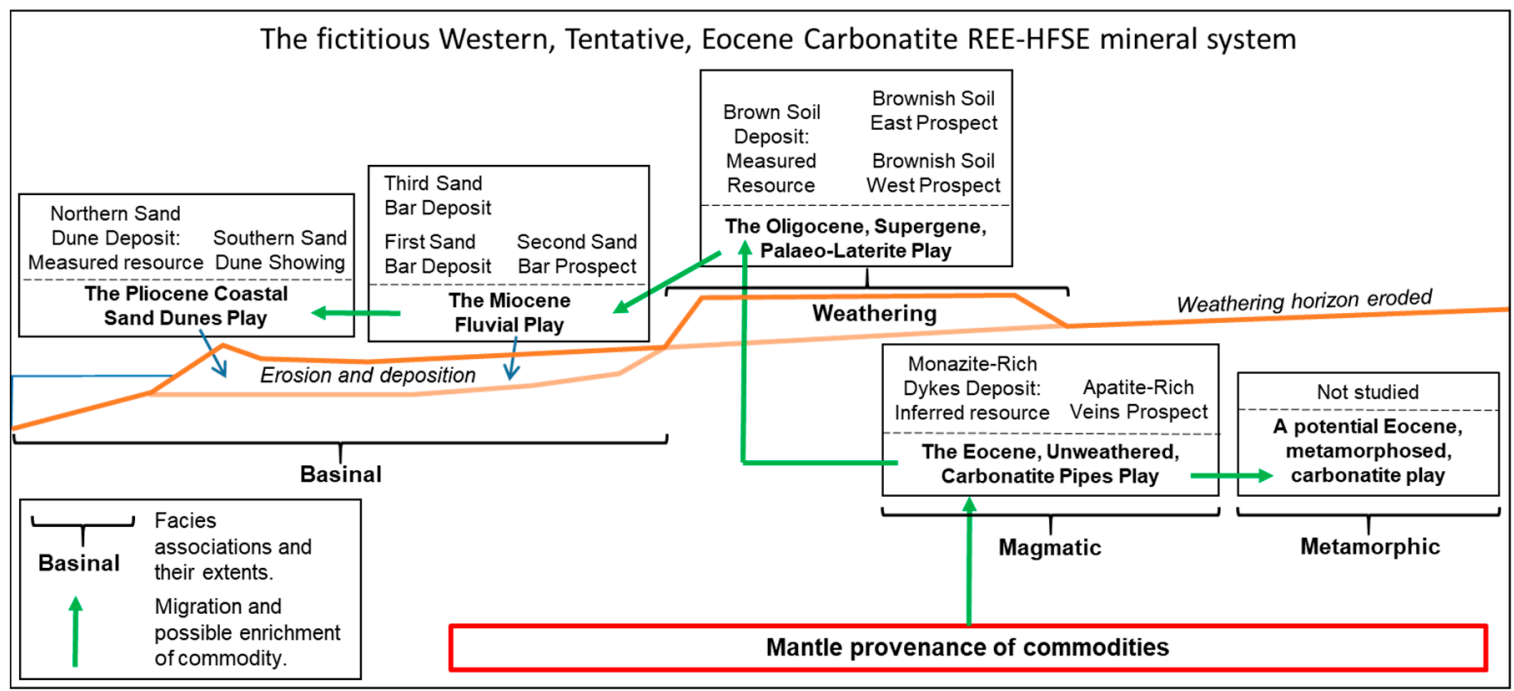

Figure 5. A schematic display of a single mineral system's possible extent and possible examples of its facies associations, plays, deposit types and prospect types. It emphasizes how genetically linked deposits and prospects form plays, and that plays are genetically linked "branches" from one mantle provenance "root". 


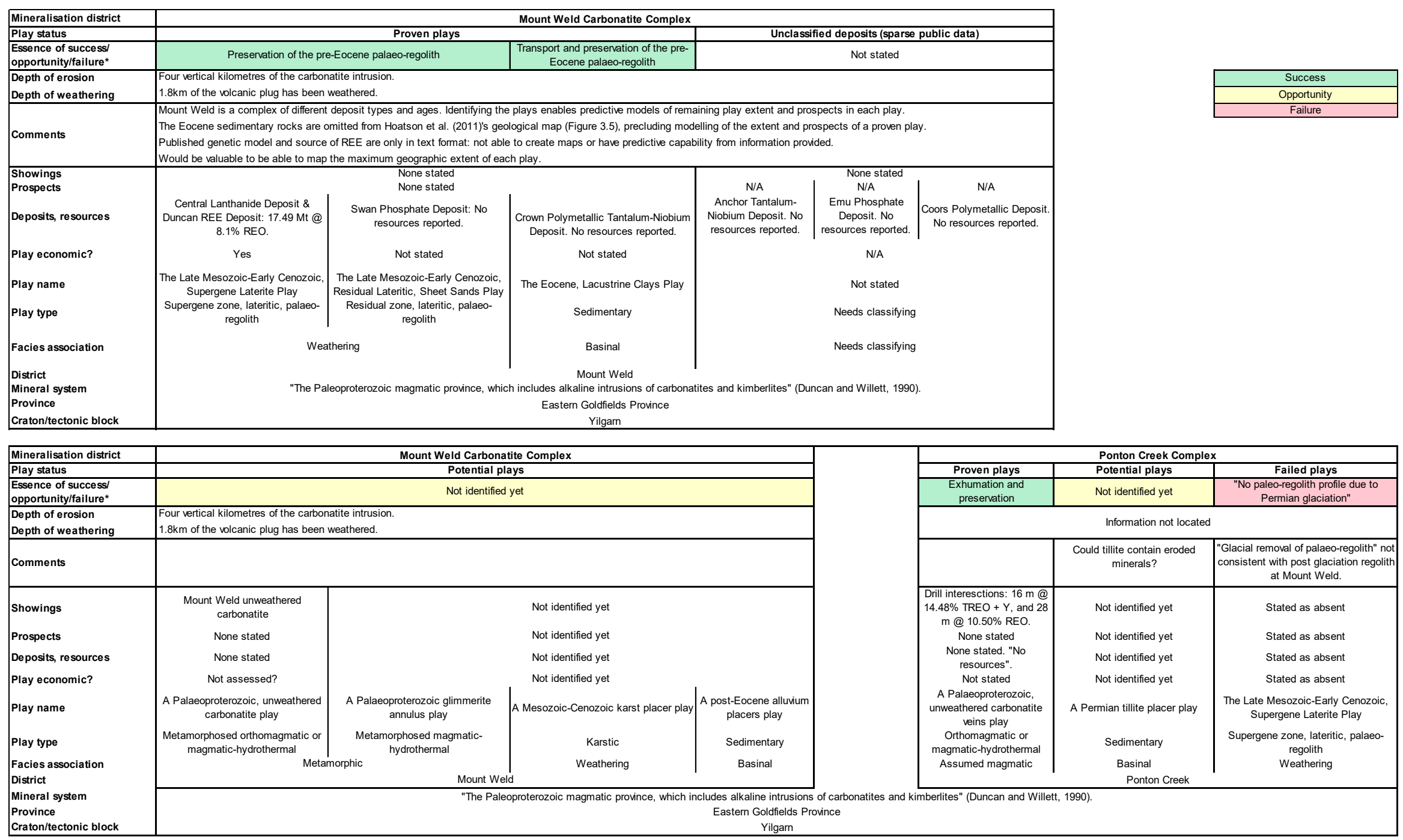

Figure 6. The Mount Weld Carbonatite Complex and Ponton Creek Complex (Australia) deposits and potential prospects organised within a scale-based, play-centric hierarchy of mineral system sub-divisions. Data from References [42,61-63]. 
Facies Associations and Enrichment Vectors

A mineral system's REE-HFSE load may—after expulsion from the provenance-be either focused or dispersed during crustal and surface migration. Commodity concentration can occur by magmatic processes between provenance and upper crust (Figure 3.3 of Reference [42]), then further 'enriched' by subsequent metamorphic, weathering, and basinal processes. Hypothesizing all the possible REE-HFSE concentrating processes along the lithospheric-scale geodynamic evolution cycle is therefore vital, because the formation of an economic deposit requires commodity concentration by orders of magnitude. A carbonatite or alkaline igneous-associated REE-HFSE mineral system may extend over as many as four facies associations (Figure 4; Figure 3.3 of Reference [42]) that the initial commodity load could be distributed in today (adapted from Reference [42]).

1. Magmatic facies association, with deposit types formed by fractionation of REE-HFSE-enriched mantle melts and/or associated hydrothermal fluids, e.g., the Mountain Pass REE deposit [8,12].

2. Weathering facies association, with deposit types formed by weathering of REE-HFSE-bearing magmatic rocks and further chemical concentration of commodities in the residual material, e.g., the Mount Weld palaeo-regolith Central Lanthanide REE Deposit (Figures 6 and 7; Reference [42]).

3. Basinal facies association, with deposit types formed by physical concentration during sedimentary processes, e.g., the lacustrine Crown Tantalum-Niobium Deposit in the Mount Weld Carbonatite Complex (Figures 6 and 7; Reference [42]).

4. Metamorphic facies association, where deposit enrichment may occur due to regional or contact metamorphic fluids, heat, and pressure, e.g., Bayan Obo Fe-REE deposit [11,64].

These facies associations are a logical foundation towards identifying mineralized plays and conducting Play Analysis. They can also be useful exploration indicator vectors. For example, a magmatic mineralization may be used as a locus for proximal fluvial deposits, whilst lateritic deposits may indicate a location of under cover magmatic mineralization. These four facies associations incorporate the lithofacies associations concept and methodology of Reference [52], and maintain alignment with "magmatic-related", "metamorphic-related", and "basin- and surface-related" "mineralizing system families" [25]. They also parallel the four REE "mineral system associations" [42], except that we expand those authors' Regolith "Mineral-system association" [42] to Weathering, to accommodate the possibility of karst-associated mineralization in weathered carbonatite bodies.

REE-HFSE mineral systems in spatially or temporally disparate provinces could acquire fundamentally similar mineral deposit characteristics due to similar geodynamic evolution cycle stages, palaeo-geographies or palaeo-climates. Therefore, analyzing facies associations in one REE-HFSE mineral system can then provide analogues for genesis, richness, and value of under-evaluated districts in another REE-HFSE mineral system.

Few historically and currently mined REE-HFSE deposits are magmatic facies association deposits, despite the volume of magmatic REE-HFSE mineralization research. Most of the mined deposits represent weathering and basinal facies associations, i.e., lateritised carbonatites, lateritic ion-adsorption clays, and sediment placers (e.g., Reference [9]). Focusing on potential REE-HFSE basinal and weathering deposition environments could therefore enhance exploration interest and probability of global geological success. Additionally, because REE metallurgic processing can be complex and expensive, and for numerous minerals still in test phase (e.g., References $[65,66]$ and references within,) summarizing a REE-HFSE mineral system's facies associations can help envisage where and how geological processes may have conducted some natural beneficiation. 


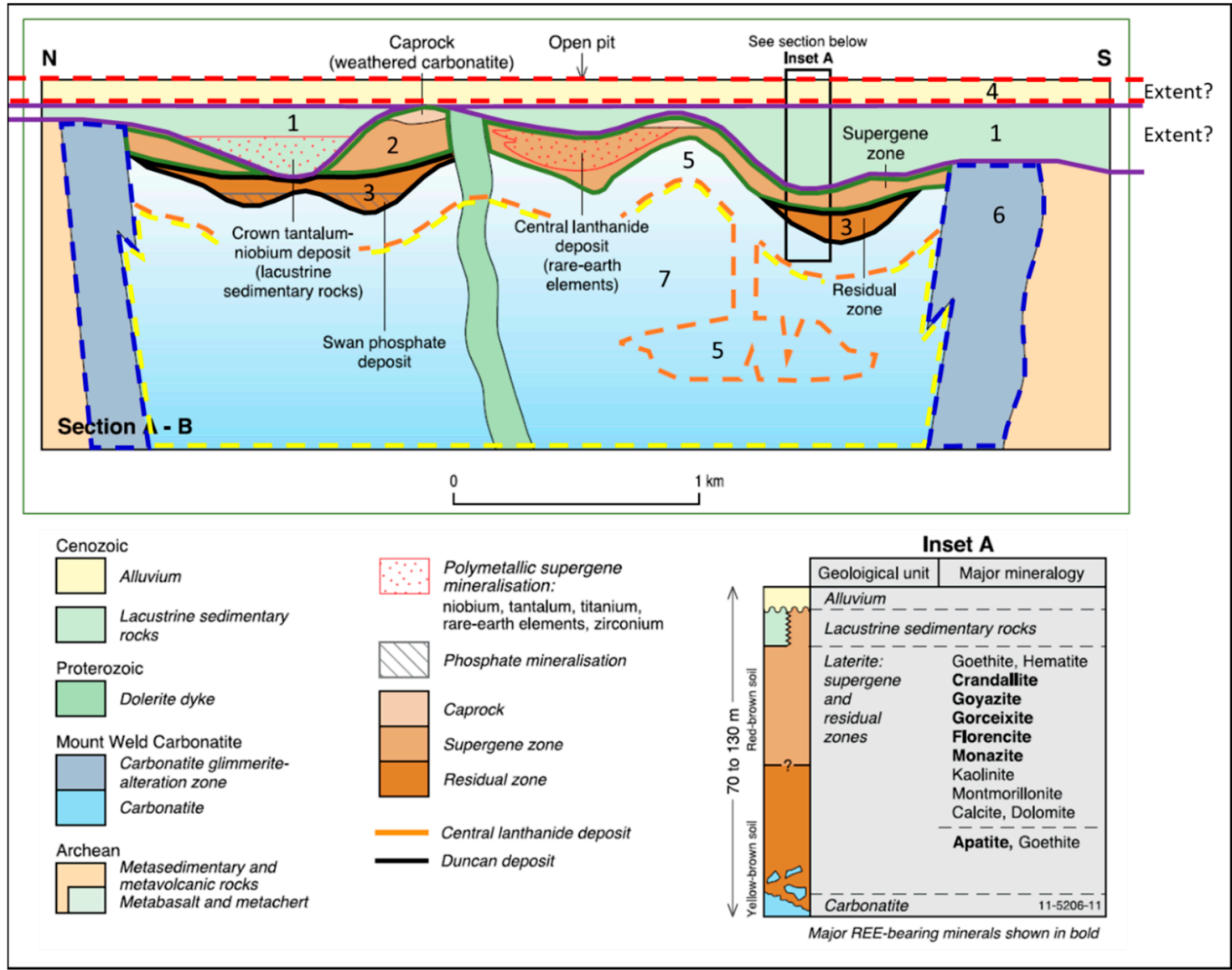

(a)

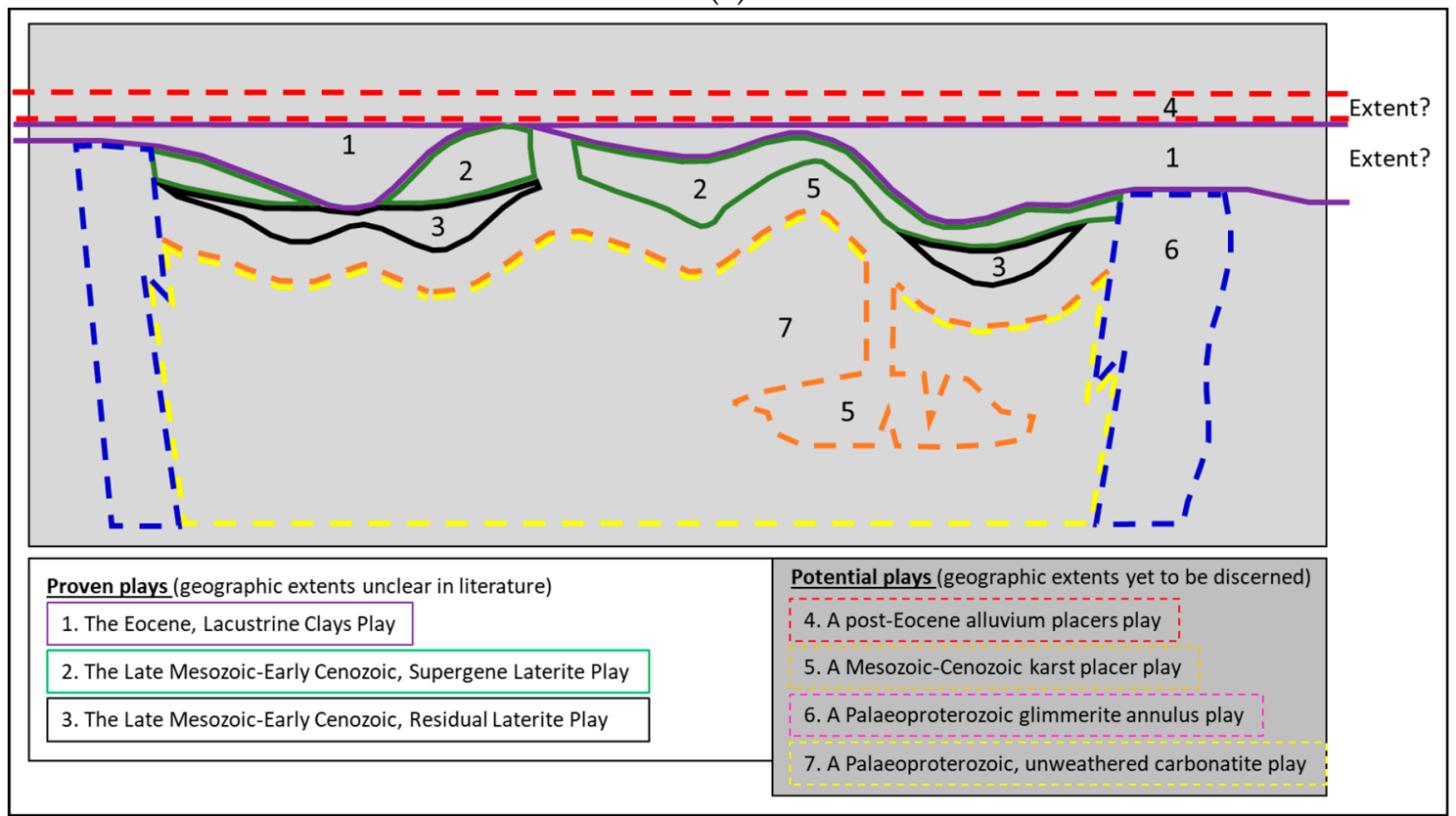

(b)

Figure 7. (a): A schematic cross-section of the Mount Weld Carbonatite Complex [42]. (b): divided in this study into mineral plays (modified after [42] and using data from References [42,61-63]. Figure 7a is reproduced with permission from Commonwealth of Australia (Geoscience Australia) 2018. This product is released under the Creative Commons Attribution 4.0 International Licence. http://creativecommons.org/licenses/by/4.0/legalcode. 
Play Types

Each of the four REE-HFSE facies associations is a group of REE-HFSE play types (deposition processes):

- Magmatic facies play types are: Orthomagmatic, magmatic-hydrothermal.

- Weathering facies play types are: Supergene zone lateritic, residual zone lateritic, karstic.

- Basinal facies play types are: Sedimentary, diagenetic-hydrothermal.

- Metamorphic facies play types are: Research is ongoing.

Recognizing play types enables a mineral system to be investigated as a potential stack of chronostratigraphic groups (plays), with each group containing process-specific deposit types. For example, the Mount Weld ore deposit (Figures 6 and 7) is a stack of three ore deposit types [42,61-63], each of a different play type and age, yet all sourced from one Palaeoproterozoic, metamorphosed, carbonatite body:

- The Eocene, basinal, sedimentary, Crown Tantalum-Niobium Deposit.

- The Late Mesozoic-Early Cenozoic, weathering, supergene palaeo-lateritic, Central Lanthanide Deposit.

- The Late Mesozoic-Early Cenozoic, weathering, residual palaeo-lateritic, Swan Phosphate Deposit. Plays

A carbonatite or alkaline igneous-associated REE-HFSE play type may contain one or more mineralized plays. A play is here defined as a group of geologically related ore deposits, mineral deposits and untested prospects within a chronostratigraphic unit (adapting the standard hydrocarbon play definition, e.g., Reference [51]). Play is most appropriate entity and term as it brings chronologic and genetic context to mineralization zones. A play is not synonymous with a deposit. Each mineralized play could comprise several deposit types. As one ore deposit is a product of the processes that generated a play, understanding how a proven mineralized play operated provides predictive capability and appropriate analogues, to seek and develop other prospects within that play. To build a probabilistic REE-HFSE prospect portfolio the base unit of targeting should be a chronostratigraphically-bound play, rather than a deposit. For example, organizing the Mount Weld REE-HFSE complex into chronostratigraphic play types reveals three proven plays (each containing mineral deposits) and four potential plays (Figures 6 and 7) spanning a variety of processes and ages. Assigning mineral deposits into their host plays would also help clarify the literature's mix of deposit settings, processes, and locations under the umbrella term 'Deposit types' (Tables 2 and 3).

Table 2. The known mineral endowment (size) of one mineral system.

\begin{tabular}{cccccc}
\hline $\begin{array}{c}\text { Resource } \\
\text { Name }\end{array}$ & $\begin{array}{c}\text { Discovery } \\
\text { Year }\end{array}$ & $\begin{array}{c}\text { Play } \\
\text { Name }\end{array}$ & Commodity & $\begin{array}{c}\text { Produced Mineral } \\
\text { Resources (e.g., Tonnes) }\end{array}$ & $\begin{array}{c}\text { Unrecovered Mineral } \\
\text { Resources (e.g., Tonnes) }\end{array}$ \\
\hline X & & & & & \\
Y & & & & \\
Z & & & sum & + & sum \\
\hline Total (tonnes) & & & & & \\
\hline
\end{tabular}

Table 3. How to express the level of certainty of a mineral system in its name (adapted from Reference [49]).

\begin{tabular}{cl}
\hline Level of Certainty & \multicolumn{1}{c}{ Criteria } \\
\hline Proven & A clear, positive correlation between mineral occurrences and provenance. \\
Tentative & $\begin{array}{l}\text { Positive geochemical evidence in the absence of a mineral } \\
\text { occurrence-provenance correlation. }\end{array}$ \\
Speculative & Mineralogical or geophysical inference. \\
\hline
\end{tabular}


Mineralization Types and Host Lithologies

Assigning each play's mineralization types into ore deposits, mineral deposits, untested prospects, and mineralization observations clarifies the extent and exploration maturity of each play. Categorizing the mineralization types into their host lithologies can indicate optimal lithologies (mappable proxies) for investigation priority.

An example of successful exploration-production along an entire mineral system's length and in its various plays is from the diamond industry of South Africa and Namibia [67-73]. It has yielded success in several facies associations, play types and plays i.e. diamond discoveries from 'primary' kimberlite sources to younger, downstream Orange River and offshore Atlantic plays, e.g.,:

- Upper Cretaceous kimberlite pipes.

- Miocene Proto-Orange alluvial river gravels and Plio-Pleistocene Meso-Orange river terraces.

- Mid Pleistocene-Holocene palaeo-shoreline and palaeo-beach sediments.

- Plio-Pleistocene raised palaeo-beach deposits.

- Pleistocene-Holocene shallow marine submerged beach deposits and seafloor bedrock.

To explore and discover diamonds, it is wise to explore all along the mineral system and not just the magmatic facies association, because less than 1\% of Earth's 6400 kimberlite occurrences will yield an economically-viable diamond deposit [70], and some economic beneficiation occurs by diamond transport and redeposition. Although REE-HFSE minerals are not as durable as diamonds, a similar holistic approach could add success to REE-HFSE targeting.

(5) Task 5. Estimate the Known Mineral Endowment (Size) of the Mineral System

The size of one mineral system is the total sum of produced and unrecovered REE-HFSE mineral resources yielded from the system's provenance, and estimated in compliance with a resource reporting code (Table 2). The size will only represent the availability of known mineral resource and production data at the time of mineral system investigation, and not the system's total mineralization/exploration potential. Documenting the size is crucial to communicate the extent of knowledge and uncertainty ranges about the system's mineralization and historic exploitation. A list of mineral occurrences without a formal mineral resource category should also be created to emphasize known remaining potential.

The mineral system's size is one way to compare mineral systems. It can also be used to determine the system's yield-mineralization efficiency: the ratio (as a percentage) of the total known REE-HFSE mass accumulated (as opposed to dispersed to background) versus the estimated total mass of REE-HFSE yielded from mantle provenance partial melting (adapted from Reference [49]). This ratio could be used for basic yet-to-find estimates, to subsequently estimate and compare the remaining potential in mineral systems. We recognize that a method to estimate the total mass of REE-HFSE mobilized during a provenance partial melting and expulsion event may not yet be available, and recommend the REE-HFSE research community consider how it could be formulated and tested.

(6) Task 6. Name the Mineral System

Geological entities, e.g., rock units, fossil species, orogenic zones and basins are assigned unique names to aid identification. Each mineral system also needs a name to distinguish it from other mineral systems. We recommend a standardized naming convention with several parts (adapted from Reference [49]):

- The geological province/region.

- The certainty of the correlation between the commodity provenance and occurrences (Table 3).

- The event most likely to have enriched the provenance in the commodity.

- The age and name of the play containing the largest volume of initially in-place resource, or data.

- The commodity. 
An example is the Southwest Germany, Tentative, Variscan-Miocene Carbonatite REE-HFSE mineral system that contains the much-published Kaiserstuhl Volcanic Complex (KVC).

(7) Task 7. Map the Mineral system's Known Extent

Mapping a mineral system's known geographic, stratigraphic and temporal extents-across all facies associations-is conducted to identify possible play extensions and new play concepts that could contain additional deposits and value. In addition, a mapped mineral system provides an objective foundation to determine exploration risk of its plays and prospects (modified from Reference [50]). A map is used to show the geographic extent, a cross section for the stratigraphic extent (depth and age range) and a preservation history chart to determine the mineralization critical moment and temporal extent. For example, a magmatic facies association critical moment is the geologically short "moment" when the critical components overlapped to enable the mineral system's largest REE-HFSE resource proportion to migrate to the initial magmatic emplacement environment, i.e., peak mineralization (modified from Reference [49]). The preservation time begins at the primary expulsion-migration-emplacement period and must extend to the present day for any deposit to still exist. It spans all physical or chemical alteration, concentration, re-migration and re-deposition events after REE-HFSE magmatic emplacement (modified from [49]).

\section{(8) Task 8. Summarize the Mineral System's Favorability for Undiscovered Mineral Endowment}

Listing under-evaluated mineral plays and their mineral occurrences indicates how the remaining mineral system prospectivity may be distributed. These plays will need comparison to appropriate, economically viable, mineral system analogues to sense-check if they may be realistic and feasible. To indicate if a carbonatite- and alkaline igneous-associated REE-HFSE mineral system has the potential to yield more commodity volume and prospective play opportunities that warrant further evaluation, the favorability of each critical component should be qualitatively summarized for each facies association, as demonstrated for the magmatic facies association here.

- Fertility. The sub-lithospheric mantle provenance received sufficient enrichment and focus of REE-HFSE and ligands (by metasomatic processes, e.g., Reference [74]), then later received sufficient heat or confining pressure reduction (for low degrees of partial melting) to expel melts that can yield a REE-HFSE mineral deposit to the upper crust.

- Whole-lithosphere configuration. Pre-existing, sub-vertical, deformation networks were prone to transient, lithospheric-scale failure [31] and permeability (e.g., weak zones at the margins of cratonic blocks [38]) to facilitate migration of mantle-derived primary magmas.

- Transient geodynamics. A transient period occurred for prevailing geodynamics to favor Self-Organised Critical System processes [31] to organize and focus fluid flux, e.g., transient compressional anomalies, incipient extension, or changes in far-field stress [23].

- Exhumation-preservation. An intrusive mineral deposit needs to have been sufficiently exhumed to enable near-surface mining, yet sufficiently preserved from erosion to retain an attractive commodity mass. For example, the Mount Weld carbonatite REE-HFSE deposit is viable whilst the same province and age Ponton Creek carbonatite is not viable due to the latter's eroded pre-Eocene palaeo-regolith [63].

Critical mineral system components with encouraging favorability are not, by themselves, an exploration targeting model. To prioritize data acquisition, an exploration targeting model or research investigation needs to list targeting criteria that are mappable in available, or realistically obtainable data sets [37]. We recommend the four-step process of [37] that translates a mineral system's: (1) Critical components into, (2) constituent processes into, (3) targeting elements reflected in a province's geology into, and (4) mappable targeting criteria used to verify that the critical components occurred. This translation is crucial for subsequent Play Analysis and Prospect Maturation stages, and is the link between Mineral system science to Targeting science (Figure 1). This four-step translation will 
be conducted again at both district and deposit scales as the geological processes, project aims and key data types vary at each targeting scale [37]. The translation of province-scale magmatic facies critical components into mappable, targeting criteria for carbonatite- and alkaline igneous-associated REE-HFSE mineral systems is ongoing in our research. Once the critical components of each facies association are translated into mappable targeting criteria, the maximum possible extent for the entire mineral system is sketched to visualize the mineral system's under-evaluated extent. If an exploration company does not have sufficient expertise in all facies associations it should expand its team, otherwise pursue only the facies associations aligned to the company's strengths and consider farming-out acreage dominated by the other facies associations. Conversely, a geological survey should attempt to research all a mineral system's facies associations to maximize a nation's REE-HFSE understanding.

\section{Case Study: The Southwest Germany, Tentative, Variscan-Miocene Carbonatite REE-HFSE Mineral System}

This case study sequentially follows the Section 2 workflow tasks to define a mineral system. This mineral system was chosen because: (a) it is exploration-immature, (b) it has several REE-HFSE mineral occurrences and a test mine, (c) the Upper Rhine Graben basin's (URG) tectonostratigraphic evolution is well-imaged (a large volume of moderately good quality 2-D reflection seismic as well as drill hole and wellbore data), (d) a substantial volume of geophysical, geochemical and borehole data (acquired 2016-2018 [75]) is currently being integrated across the Kaiserstuhl Volcanic Complex (KVC) district, and (e) its mineralization potential has not been evaluated via a mineral system approach. Its "greenfield" status means some workflow tasks cannot be completed yet.

The Southwest Germany, Tentative, Variscan-Miocene Carbonatite REE-HFSE mineral system is located in the southwest Germany part of the Central European Volcanic Province (e.g., Reference [76]). The magmatic facies of the mineral system was emplaced during several pulses of alkaline magmatism between 117 and $0.01 \mathrm{Ma}$ (Figure 8; [77,78] and references therein). It is onshore in a seismically active (e.g., Reference [79]) Eurasian intraplate location, proximal to the uplifting North Alpine Foreland Basin and Alps orogenic belt (Figure 8). The region formed by the amalgamation of supra-subduction zone micro-plates during the Devonian-Carboniferous Variscan Orogeny [80]. The mineral system is located in and around the Southern URG basin (Figures 8 and 9). The basin contains up to 3 $\mathrm{km}$ of terrestrial and shallow marine sedimentary rocks (e.g., Reference [81] and references therein; Figure 10) deposited during mid-Eocene to Oligocene lithospheric-scale transtension, e.g., [82-85], beneath and up to $300 \mathrm{~m}$ of Quaternary gravels (e.g., Reference [81]). Early Miocene to present-day sinistral transpression, uplift, northward tilting and erosion of the URG and Vosges-Schwarzwald arch, e.g., References $[81,84-87]$ may have been an indentation tectonics response to northward propagation of The Alps fold-thrust belt. This may have also caused hundreds of meters of Cenozoic erosion off the circum-URG alkaline igneous regions $[87,88]$. The province has not undergone significant metamorphism during the mineral system's 117 Myr of geologic evolution. REE-HFSE-mineralized igneous bodies cluster around intersections of $100 \mathrm{~km}$-scale structural lineaments (Figure 8) that may have formed or been reactivated during a series of tensional, contractional or wrench deformation phases. Magmatic ascent of REE-HFSE may have exploited episodic permeability through these pre-existing structures. The climatic and weathering evolution of the province have not yet been assessed in this research project, and would be required for further mineralization investigation. The mineral system's critical components are assessed at province-scale for favorability to generate a magmatic facies mineral deposit. Play types and plays are also summarized. For an overview of KVC district, refer to Reference [78] and the references within.

This mineral system's magmatic facies association at the KVC district hosts one mineral deposit discovery to date: a historic niobium test mine that yielded 8000 tonnes of carbonatite with $0.2 \%$ to $0.35 \% \mathrm{Nb}_{2} \mathrm{O}_{5}$ ([89] and references therein). Other mineral occurrences include REE-HFSE-enriched carbonatite apatite and pyrochlore mineral grains in outcrop and drill core occurrences, with recent whole rock analyses showing concentrations up to $8000 \mathrm{ppm}$ total rare earth oxides (TREO) [78]. 
REE-HFSE and isotope analyses link mineralization occurrences within the KVC district. Pyrochlore grains provide a niobium mineralogy correlation between the KVC and Herboltzheim ("URG" on Figure 8; [90]) districts. The mineral system extent has been extrapolated to REE or HFSE mineralization occurrences (Figures 8 and 10) in more than 50 other alkaline igneous bodies [91,92]. Detailed trace element analysis of mineralization occurrences is yet to be conducted, however the carbonatitic and alkaline igneous REE-HFSE 'transporter' lithologies indicate positive petrological correlations (Figures 8 and 10) and mappable proxies for potential mineralization. These mantle-originating lithologies and mantle xenoliths across the province (Figure 8) suggest a mantle provenance of their REE-HFSE. Nd-, $\mathrm{Sr}-, \mathrm{Nd}-$, and $\mathrm{Pb}$ - isotope analyses at the KVC district indicate metasomatic mantle enrichment of REE-HFSE that is tentatively inferred to Variscan subduction events. The detailed REE-HFSE analyses to date suggest an encouraging Lower Miocene, un-weathered carbonatite REE-HFSE play containing several prospects (Figure 9). Other HFSE occurrences indicate potential Cretaceous and Cenozoic magmatic plays that need further defining (Figure 9).

The known mineral system extent envelopes the surface carbonatite and alkaline igneous rocks containing HFSE-bearing minerals (Figure 8). REE mineralization has also been measured to $340 \mathrm{~m}$ below the surface (elevated La concentrations on KVC carbonatite borehole core KB3 [75]). 


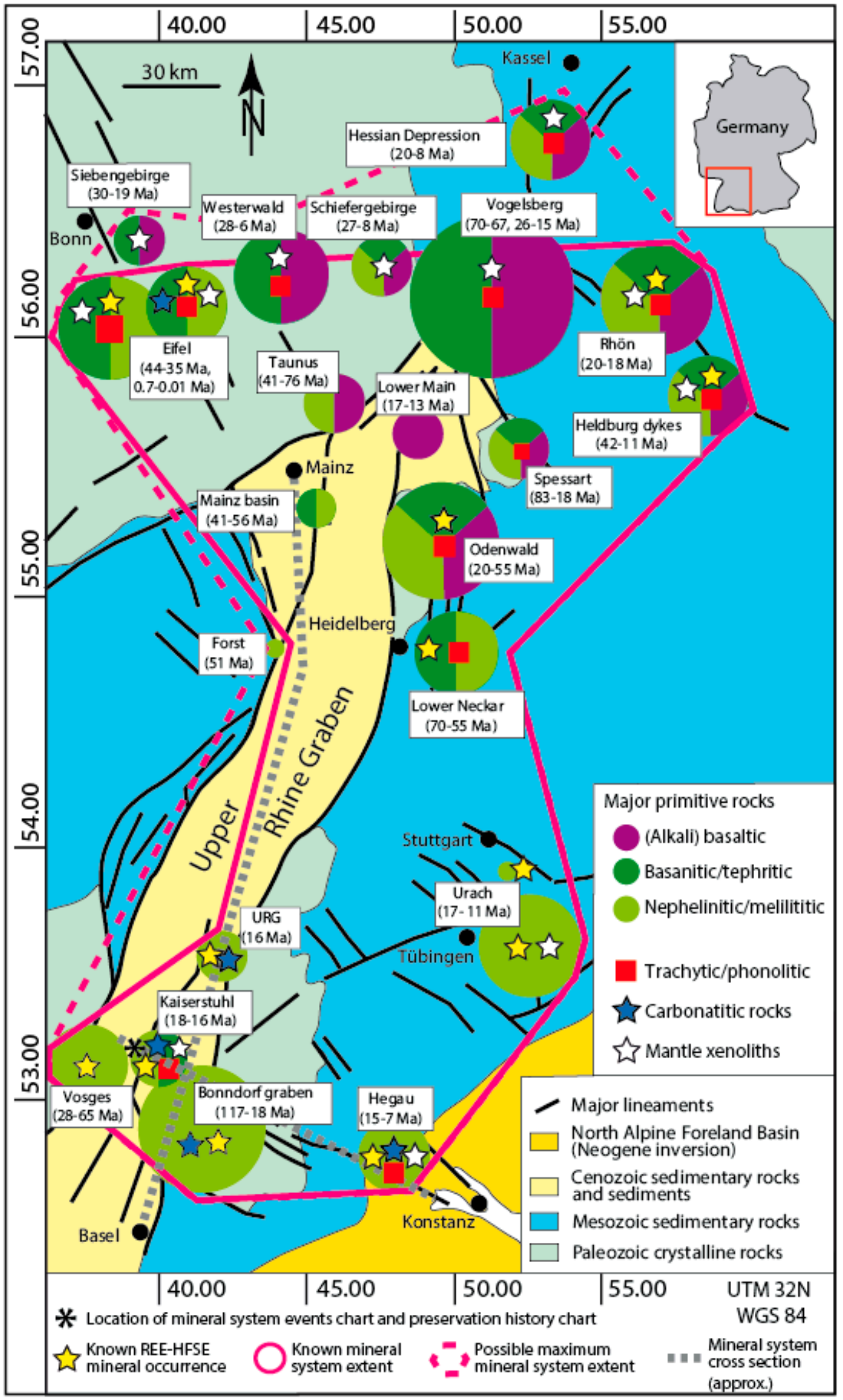

Figure 8. The present-day known and maximum possible geographic extents of the Southwest Germany, Tentative, Variscan-Miocene Carbonatite REE-HFSE mineral system, using features from References $[78,93]$. The size of the circles corresponds to generalized geographic areas over which the alkaline igneous bodies cluster. 


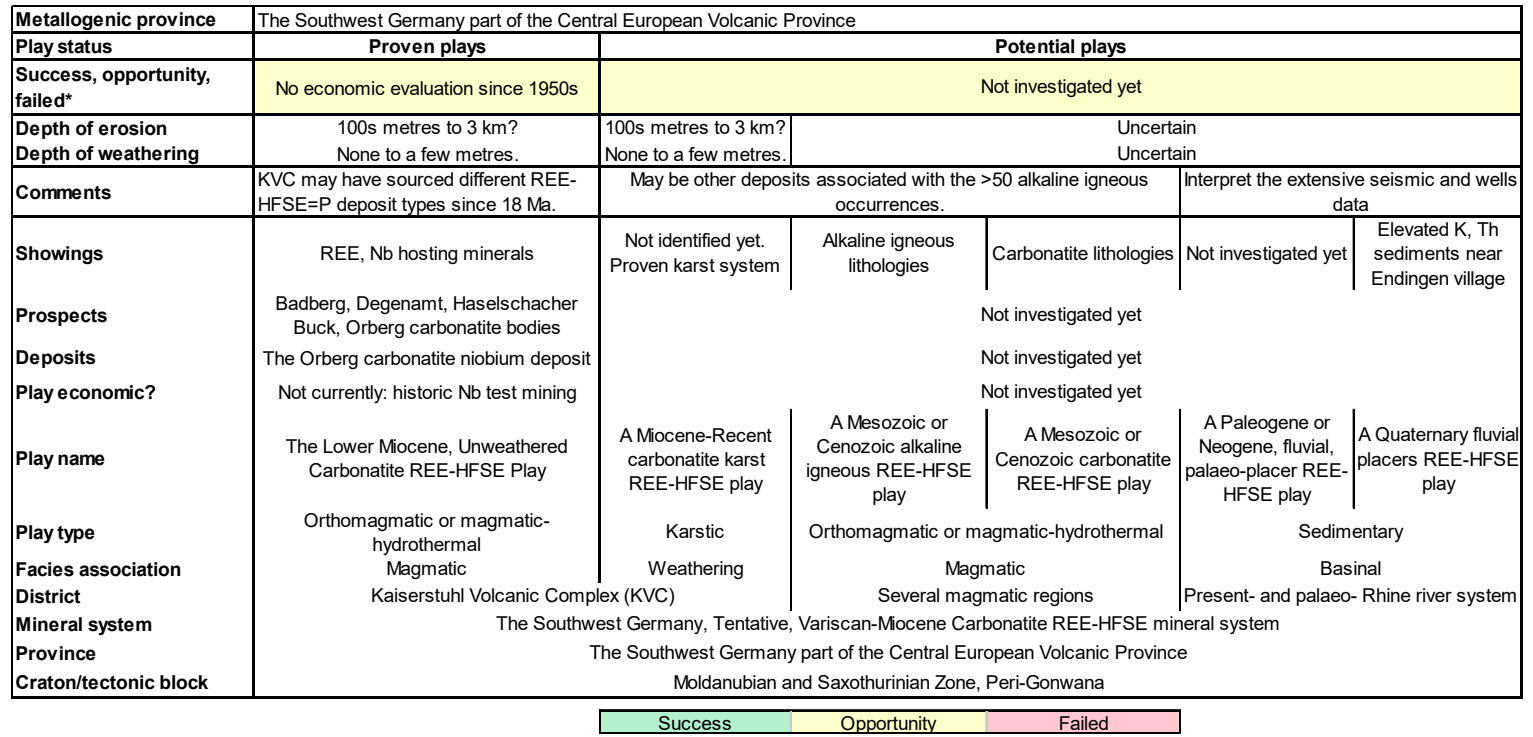

Figure 9. The known and potential plays of the Southwest Germany, Tentative, Variscan-Miocene Carbonatite REE-HFSE mineral system organized within a hierarchical, play-centric scheme. Features are from References [75,76,80,89].

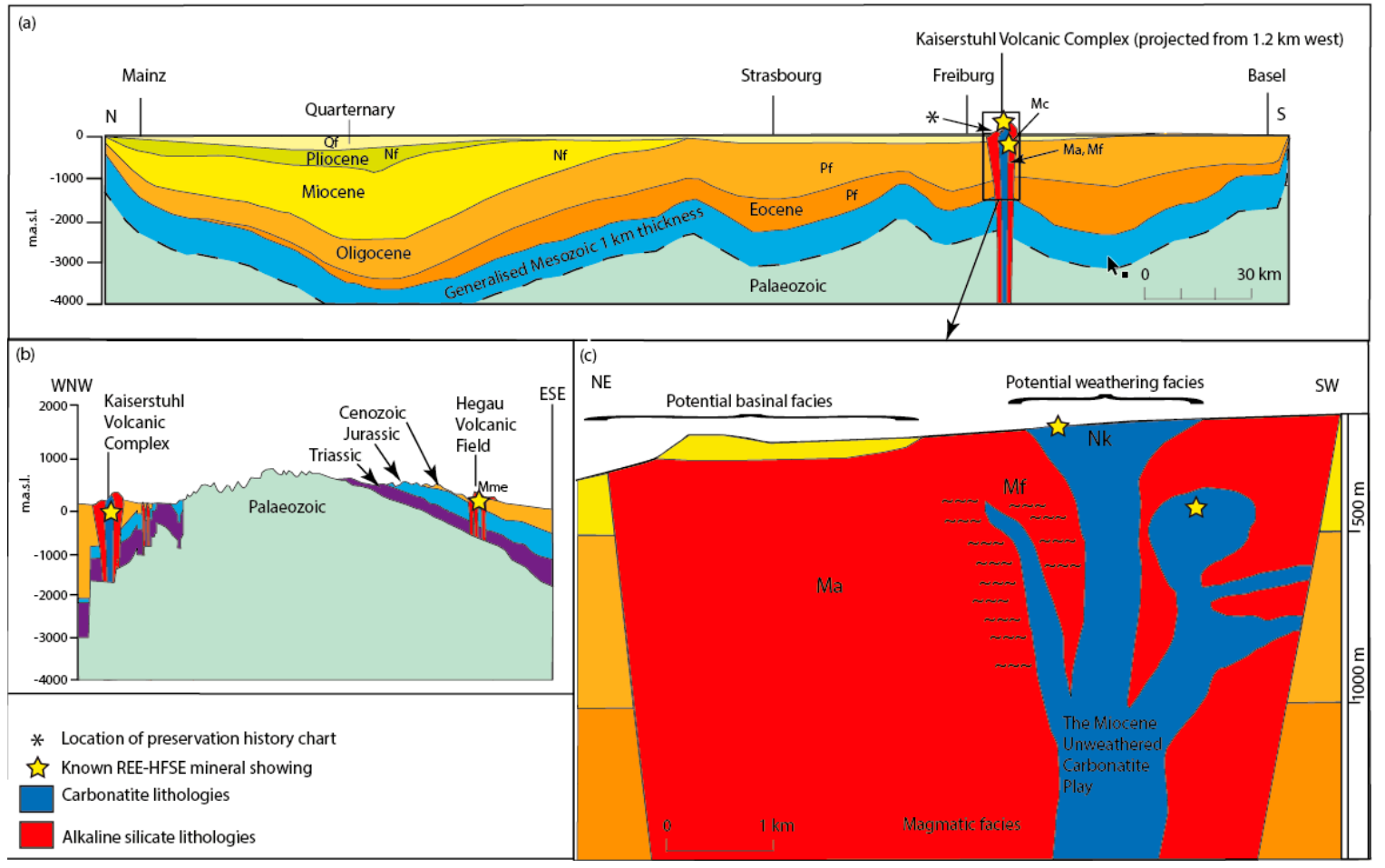

Figure 10. The present-day stratigraphic extent of the Southwest Germany, Tentative, Variscan-Miocene Carbonatite REE-HFSE mineral system, and its known and potential plays, using features from Reference [93]: (a) Potential Cenozoic basinal plays along the Upper Rhine Graben basin; (b) Potential Cenozoic magmatic plays in SW Germany; and (c) Potential Neogene magmatic plays at KVC district. Numerous faults have been omitted for diagram clarity. Note vertical exaggeration. Potential REE-HFSE plays: Qf: Quaternary fluvial; Nf: Neogene fluvial; Pf: Paleogene fluvial-lacustrine; Mc: Miocene carbonatite; Ma: Miocene alkaline silicate intrusion; Mf: Miocene fenitisation; Nk: Neogene karst; Mme: Miocene maar extrusive pipe; and Mmi: Miocene maar intrusive pipe. The locations of these cross sections are shown in Figure 8. 
The mineral system may span $117 \mathrm{Ma}$ (Figure 8). In the KVC district the mineral system's temporal extent and preservation duration is c.18 Myr, from the earliest KVC REE-HFSE magmatism [94] to the present-day REE-HFSE mineralization occurrences (Figures 8 and 9). The critical moment for mineralization is currently placed at $15-18 \mathrm{Ma}$, i.e., associated with the timing of the niobium-mined carbonatite body and the most-studied magmatism.

The temporal sequence of critical components for a chance of a magmatic REE-HFSE deposit in KVC district is encouraging (Figure 11): A palaeo supra-subduction zone mantle wedge may have been metasomatized before lithospheric permeability enabled REE-HFSE-enriched magmas to be emplaced, temporally close to a change in regional stress, all before exhumation to near-surface and only partial erosion. The preservation history chart (Figure 12) displays that the 18-15 Ma [94] emplacement of the KVC REE-HFSEs coincided with a reversal from tectonic subsidence to uplift. It seems KVC emplacement was related to contractional/transpressional tectonism, which could be related to the nearby Alps orogeny [88] and related tectonic reconfiguration [95].

The Miocene and Carbonatite parts of the mineral system's name reflect the peak mineralisation being assigned to Miocene carbonatite play in the KVC district (the only proven play and adequate data-knowledge volume) whilst Variscan-related provenance metasomatism remains tentative. The mineral system's known mineral endowment is currently documented as c.20 tonnes (only incorporates the known $\mathrm{Nb}$ production from the Ohrberg quarries [89]). This tonnage is limited by non-geological factors, i.e., the availability of published REE-HFSE resource data and the few REE-HFSE mineralization investigations. It is unlikely to reflect the total REE-HFSE mineral endowment across SW Germany. A simple estimate of the KVC district's resource potential in the various commodity-bearing minerals may be possible after ongoing mineralogical and subsurface geophysical studies are interpreted and integrated. A source yield-mineralization efficiency estimate has not yet been conducted.

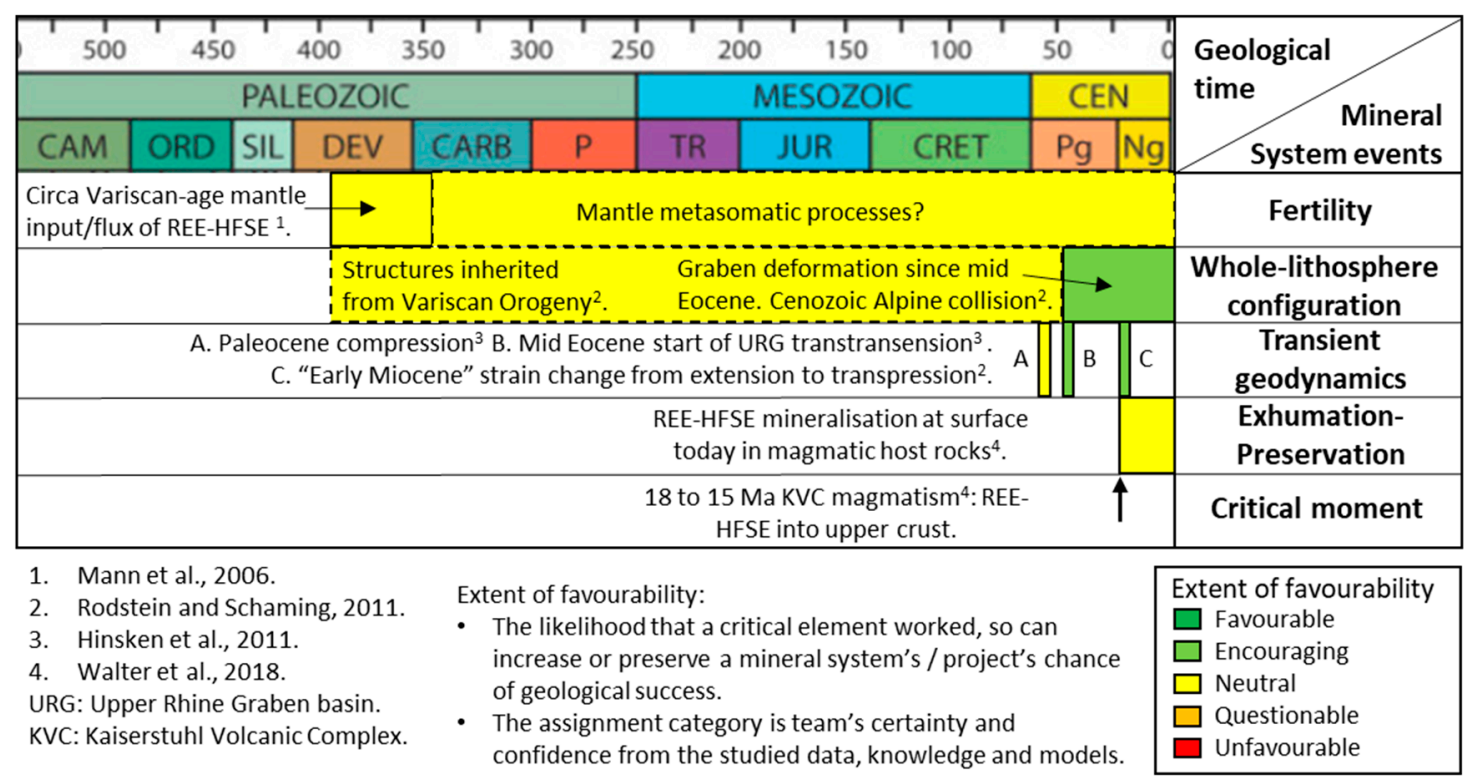

Figure 11. A mineral system events chart showing the province-scale, magmatic facies, critical components at KVC district, using features from References $[78,85,96,97]$. The location of this chart is shown in Figure 8. 


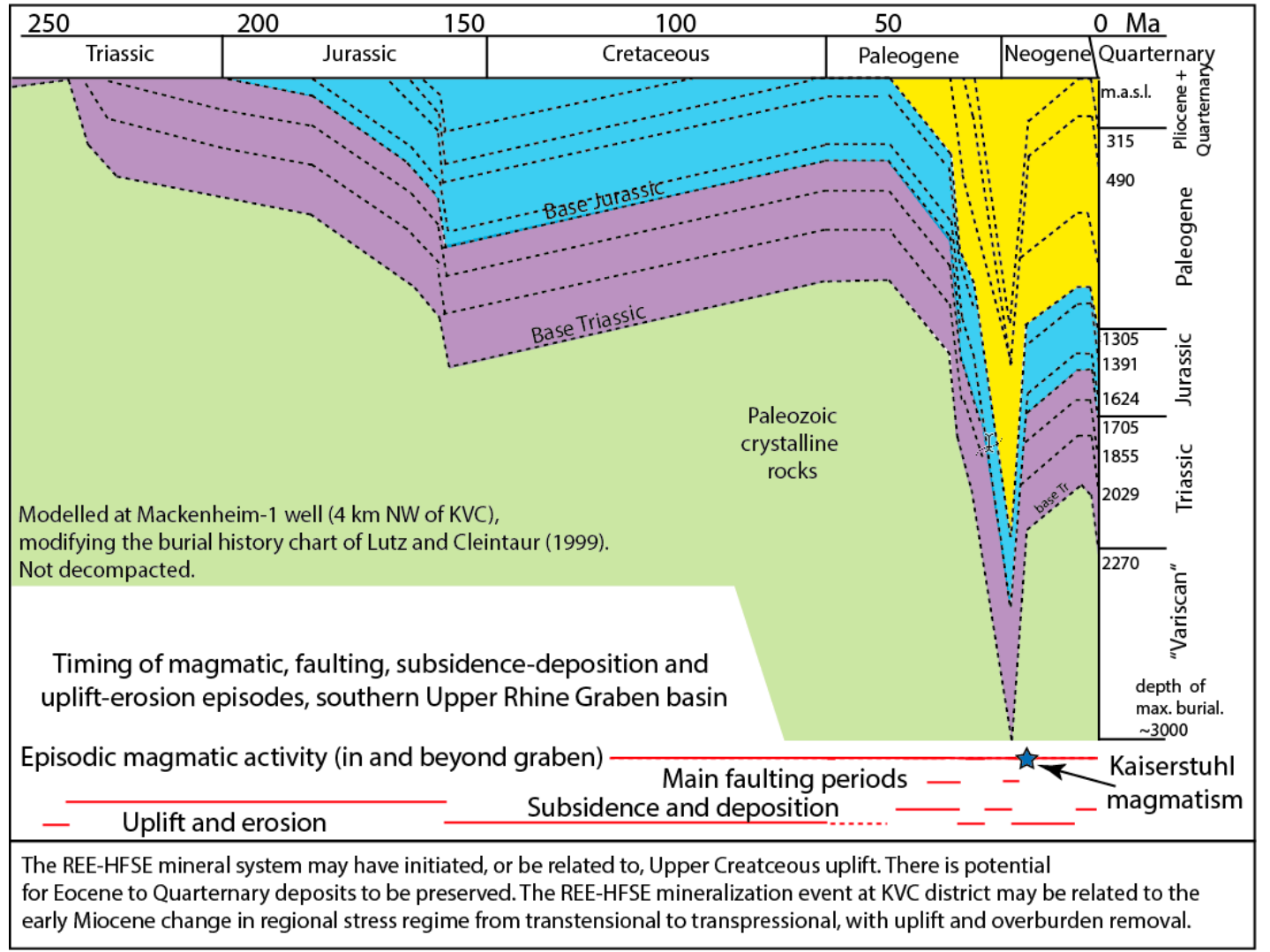

Figure 12. Preservation history chart of the Southwest Germany, Tentative, Variscan-Miocene Carbonatite REE-HFSE mineral system next to the KVC district, modified from Reference [98]. The location of this chart is shown in Figure 8.

This mineral system's encouraging geologic evolution, historic $\mathrm{Nb}$ production, trace element geochemistry and mineral exploration geophysical data collected across KVC district all indicate mineralization potential in several REE-HFSE plays (Figure 9) across the province:

- The numerous carbonatite and alkaline igneous plays could host orthomagmatic or magmatichydrothermal REE-HFSE deposits.

- Mesozoic or Cenozoic fluvial REE-HFSE plays could reside in the present and palaeo-Rhine drainage system, sourced from partly eroded carbonatite and alkaline igneous bodies. For example, the REE-HFSE pathfinder signature of elevated K and Th north of the KVC [75] tentatively indicates a Quaternary, fluvial REE-HFSE play.

- Karst-related plays with insoluble minerals deposits may exist within known carbonatite caves.

The mineral system's critical components have been qualitatively screened at the KVC district location for favourability of (a) working play likelihood, and (b) the preservation of project value (Figure 11), as listed here.

- Fertility is Neutral. No modelling of the mantle provenance's REE-HFSE and ligand enrichment, partial melting nor REE-HFSE expulsion volume has yet been conducted. The only industry evaluation was one historic niobium test mine [89].

- Whole-lithosphere configuration is encouraging. Mantle-derived alkaline igneous bodies clustering around junctions of large-scale structural lineaments prove repeated lithospheric permeability locations and events across SW Germany (Figure 11).

- Transient geodynamics is Encouraging. KVC district magma flux was temporally close to regional stress field changes, e.g., the magmatism and a c.20 Ma hydrothermal activity maxima [99] overlap with the, "Early Miocene" [85] start of URG transpression and northward Alps propagation [88]. 
- Exhumation-Preservation is Neutral. Intrusive igneous bodies at surface today show ideal exhumation and overburden removal to use direct detection technologies. However, deep erosion of Miocene-Pliocene sediments out of the southern URG during Neogene transpression [85], and $4 \mathrm{~km}$ of Cenozoic Vosges-Schwarzwald Arch uplift [87] may have removed any intrusive REE-HFSE deposits.

Using a weakest-link method for determining the overall system's favorability, Neutral favorability is currently assigned. The current weak links relate to amount of foundational research published: (a) Insufficient knowledge about source fertility and possible commodity yield, and (b) insufficient literature search about the erosion depth around magmatic mineral occurrences. The lack of any negative geological components provides optimism and justifies continued evaluation of this mineral system. Appropriate analogues for this mineral system need to be sought, as they will be vital to sense-check the validity of this, and future, mineral system evaluations. Translating province-scale critical components into mappable, targeting criteria is ongoing in our research. If Play Analysis was undertaken, after environmental and geometallurgy screening is conducted and yields no "red flags", the URG basin's abundant 2-D reflection seismic and wellbore data should be interpreted (if accessible) to map Rhine river system evolution and sub-surface mineralization indicators in magmatic and basinal facies. The emplacement of the KVC district and several other mineral occurrences during Alps encroachment, and concomitant uplift, displays the influence of regional contractional tectonics on this mineral system's existence.

The maximum possible geographic extent remains undefined due to insufficient geochemical analyses. It is currently inferred to extend to the limits of the province's alkaline igneous lithologies (Figure 8). The magmatic facies association could extend beyond the Figure 8 map boundaries, because alkaline magmas also outcrop northeast around the Eger rift (Czech Republic) (e.g., Reference [100]) and southwest in the Massive Central (France) [101]. Fluvial deposits could have been deposited beyond the magmatic facies association limit. The maximum possible stratigraphic extent could be several kilometers deep (Figure 10), although economic maximum depth would be defined by feasible mining depth. Analyses are required to show if the maximum possible temporal extent is economically viable back to the $117 \mathrm{Ma}$ host lithologies (Figure 8). There may be several, localized critical moments of mineralization, because the commodity provenance has repeatedly yielded magmatic lithologies typically associated with REE-HFSE mineralization.

\section{Summary and Outlook}

A standardized workflow to define carbonatite- and alkaline igneous-associated REE-HFSE mineral systems has been presented, to precede application of the mineral system concept and approach to REE-HFSE projects. For any carbonatite- or alkaline igneous-associated REE-HFSE evaluation project (and any other commodity system) the first step is sub-division into five, successive, targeting scales with differing decision-making goals: Province Framework, Mineral System, Play Analysis, Prospectivity Mapping and Prospect Maturation stages. The process-based workflow presented above is a 'recipe' to guide stakeholders through the Mineral System Definition stage (that can be applied to other commodities too), because a mapped mineral system provides foundation for subsequent deposit evaluations and direct-detection data acquisition. Applying this mineral system definition workflow enables mapping, key-risk listing, then targeting of carbonatite- and alkaline igneous-associated REE-HFSE mineral systems in underexplored regions, regardless of their data volume. Once a REE-HFSE mineral system has been defined, a project can switch from a descriptive to a predictive approach to generate undiscovered/under-evaluated mineral system 'branches' to target. This standardized approach and workflow provides the necessary foundation to: (a) Gain geological processes-based perspective to explore for mineral resources, (b) predictively determine the most favorable mineral system branches to target/research, (c) probabilistically risk prospects during portfolio building, (d) build analogues for other, less-defined, mineral systems, and (e) compare and rank REE-HFSE mineral systems. 
Optimal mineral exploration ground selection and prospect portfolio building can only be achieved after the extents of a mineral system's facies, processes, chronostratigraphic units, and mineralizations are mapped, then critical components translated into mappable criteria. The base unit of exploration/evaluation should be a chronostratigraphically-bound mineral play.

We recommend that industry, geological surveys, research and government policy-makers together define and rank nations' carbonatite and alkaline igneous-associated REE-HFSE minerals systems at province-scale: To focus predictive targeting, highlight knowledge gaps requiring further research and increase the projects' efficiency.

The Southwest Germany, Tentative, Variscan-Miocene Carbonatite REE-HFSE mineral system was identified, mapped and screened by this study. Its magmatic facies contains neutral to encouraging critical components at the KVC district, plus a possibility for mineral plays in untested, magmatic, basinal and weathering facies. The temporal link between the KVC district magmatism and Alps propagation justifies investigating how tectonic contraction/transpression influences REE-HFSE mineral system emplacement. The historic $\mathrm{Nb}$ mining and high TREO concentrations in the KVC district justify future industry, research and governmental attention and data acquisition: To hypothesize the undiscovered mineral endowment possible in this exploration-immature REE-HFSE mineral system. If environmental, geometallurgy, and fiscal factors were encouraging, the next evaluation stage would be Play Analysis, especially on the abundant URG sub-surface data.

Author Contributions: G.J.B. conceived and designed the workflow; G.J.B., M.A.W.M., B.F.W. and P.R.S. analysed the case study region; G.J.B., M.A.W.M. and B.F.W. contributed materials and figures; G.J.B. wrote most of the text; all authors reviewed the manuscript. Conceptualization, G.J.B., B.F.W. and M.A.W.M.; Data curation, G.J.B., B.F.W., M.A.W.M., and P.R.S.; Formal analysis, G.J.B., B.F.W., M.A.W.M. and P.R.S.; Investigation, G.J.B. and B.F.W.; Methodology, G.J.B.; Writing-original draft, G.J.B.; Writing-review \& editing, G.J.B., B.F.W., M.A.W.M. and P.R.S.

Funding: This research, and the costs to publish this in open access, are part of the HiTech AlkCarb project, under the European Union's (EU) Horizon 2020 research and innovation programme, grant agreement number [689909].

Acknowledgments: We thank Samuel Weatherley for fruitful discussions, inspiration, critique and suggestions, Jon Hronsky (Western Mining Services) for insight into the various mineral system approaches, Kathryn Goodenough (British Geological Survey) and Francis Wall (Camborne School of Mines, University of Exeter) for reviews and suggestions, Charles Beard (British Geological Survey) and Paul Ventris (GIS-PAX) for suggestions, and many GEUS and former Maersk Oil colleagues for stimulating system-scale discussions. Reviews by two anonymous reviewers greatly improved the manuscript.

Conflicts of Interest: The authors declare no conflict of interest. The founding sponsors had no role in the design of the study; in the collection, analyses, or interpretation of data; in the writing of the manuscript; nor in the decision to publish the results.

\section{References}

1. Kalvig, P.; Machacek, E. Examining the rare-earth elements (REE) supply-demand balance for future global wind power scenarios. Geol. Surv. Den. Greenl. Bull. 2018, 41, 87-90.

2. EC. Report on Critical Raw Materials for the EU: Report of the Ad hoc Working Group on Defining Critical Raw Materials; DG Enterprise and Industry (GROW), European Commission: Brussels, Belgium, 2010; pp. 1-41.

3. EC. Communication from the Commission to the European Parliament, the Council, the European Economic and Social Committee and the Committee of the Regions on the 2017 List of Critical Raw Materials for the EU; European Commission: Brussels, Belgium, 2017; pp. 1-8.

4. Pirajno, F. Intracontinental anorogenic alkaline magmatism and carbonatites, associated mineral systems and the mantle plume connection. Gondwana Res. 2015, 27, 1181-1216. [CrossRef]

5. Verplanck, P.L.; Hitzman, M.W. Rare Earth and Critical Elements in Ore Deposits; Society of Economic Geologists: Littleton, CO, USA, 2016; Volume 18, p. 319, ISBN 978-1-629492-18-6.

6. Mariano, A.N.; Mariano, A.N., Jr. Rare Earth Mining and Exploration in North America. Elements 2012, 8, 369-376. [CrossRef]

7. Verplanck, P.L.; Van Gosen, B.S.; Seal, R.R.; McCafferty, A.E. A Deposit Model for Carbonatite and Peralkaline Intrusion-Related Rare Earth Element Deposits; U.S. Geological Survey Scientific Investigations Report 2010-5070-J; U.S. Geological Survey: Reston, VA, USA, 2010; pp. 1-58. 
8. Woolley, A.R.; Kjarsgaard, B.A. Carbonatite Occurrences of the World: Map and Database; Open File 5796; Geological Survey of Canada: Ottawa, ON, Canada, 2008.

9. U.S. Geological Survey. Mineral Commodity Summaries 2018; U.S. Geological Survey: Reston, VA, USA, 2018; p. 200.

10. Chen, W.; Honghui, H.; Bai, T.; Jiang, S. Geochemistry of Monazite within Carbonatite Related REE Deposits. Resources 2017, 6, 51. [CrossRef]

11. Song, W.; Xu, C.; Smith, M.P.; Chakhmouradian, A.R.; Brenna, M.; Kynický, J.; Chen, W.; Yang, Y.; Deng, M.; Tang, H. Genesis of the world's largest rare earth element deposit, Bayan Obo, China: Protracted mineralisation evolution over $\sim 1$ b.y. Geology 2018, 46, 323-326. [CrossRef]

12. Castor, S.B. Rare Earth Deposits of North America. Resour. Geol. 2008, 58, 337-347. [CrossRef]

13. Jaireth, S.; Hoatson, D.M.; Miezitis, Y. Geological setting and resources of the major rare-earth-element deposits in Australia. Ore Geol. Rev. 2014, 62, 72-128. [CrossRef]

14. Mitchell, R.H. Primary and secondary niobium mineral deposits associated with carbonatites. Ore Geol. Rev. 2015, 64, 626-641. [CrossRef]

15. Le Bas, M.J.; Strickeisen, A.L. The IUGS systematics of igneous rocks. J. Geol. Soc. 1991, 148, 825-833. [CrossRef]

16. Berger, V.I.; Singer, D.A.; Orris, G.J. Carbonatites of the World, Explored Deposits of Nb and REE-Database and Grade and Tonnage Models; U.S. Geological Survey Open-File Report; U.S. Geological Survey: Reston, VA, USA, 2009; pp. 1-17. Available online: http:/ / pubs.usgs.gov/ of/2009/1139/ (accessed on 2 July 2018).

17. Chakhmouradian, A.; Wall, F. Rare earth elements: Minerals, mines, magnets (and more). Elements 2012, 8, 333-340. [CrossRef]

18. Wall, F. Rare Earth Elements. In Critical Metals Handbook; Gunn, G., Ed.; Wiley-Blackwell: London, UK, 2014; pp. 312-339.

19. Goodenough, K.M.; Schilling, J.; Jonsson, E.; Kalvig, P.; Charles, N.; Tuduri, J.; Deady, E.A.; Sadeghi, M.; Schiellerup, H.; Müller, A.; et al. Europe's rare earth element resource potential: An overview of REE metallogenetic provinces and their geodynamic setting. Ore Geol. Rev. 2016, 72, 838-856. [CrossRef]

20. Du, X.; Graedel, T.E. Uncovering the global life cycles of the rare earth elements. Sci. Rep. 2011, 1. [CrossRef] [PubMed]

21. Binnemans, K.; Jones, P.T.; Blanpain, B.; Van Gerven, T.; Yang, Y.; Walton, A.; Buchert, M. Recycling of rare earths: A critical review. J. Clean. Prod. 2013, 51, 1-22. [CrossRef]

22. Goodenough, K.M.; Wall, F.; Merriman, D. The Rare Earth Elements: Demand, global resources, and challenges for resourcing future generations. Nat. Resour. Res. 2018, 27, 201-216. [CrossRef]

23. McCuaig, T.C.; Hronsky, J.M.A. The Mineral System Concept: The Key to Exploration Targeting. In Building Exploration Capability for the 21st Century; Kelley, K.D., Golden, H.C., Eds.; Society of Economic Geologists: Littleton, CO, USA, 2014; Volume 18, pp. 153-175.

24. Wyborn, L.A.I.; Heinrich, C.A.; Jacques, A.L. Australian Proterozoic mineral systems: Essential ingredients and mappable criteria. In Proceedings of the Australasian Institute of Mining and Metallurgy Annual Conference, Darwin, Australia, 5-9 August 1994; pp. 109-116.

25. Skirrow, R.G.; Jaireth, S.; Huston, D.L.; Bastrakov, E.N.; Schofield, A.; van der Wielen, S.E.; Barnicoat, A.C. Uranium Mineral Systems: Processes, Exploration Criteria and a New Deposit Framework; Geoscience Australia Record 2009/20; Geoscience Australia: Canberra, Australia, 2009; p. 44.

26. Joly, A.; Porwal, A.; McCuaig, T.C. Exploration targeting for orogenic gold deposits in the Granites-Tanami Orogen: Mineral system analysis, targeting model and prospectivity analysis. Ore Geol. Rev. 2012, 48, 349-383. [CrossRef]

27. Kreuzer, O.P.; Miller, A.V.M.; Peters, K.J.; Payne, C.E.; Wildman, C.; Partington, G.A.; Puccioni, E.; McMahon, M.E.; Etheridge, M.A. Comparing prospectivity modelling results and past exploration data: A case study of porphyry Cu-Au mineral systems in the Macquarie Arc, Lachlan Fold Belt, New South Wales. Ore Geol. Rev. 2015, 71, 516-544. [CrossRef]

28. Hagemann, S.G.; Cassidy, K. Archean orogenic lode gold deposits. In Gold in 2000; Hagemann, S.G., Brown, P.E., Eds.; Society of Economic Geologists: Littleton, CO, USA, 2000; pp. 9-68.

29. Barnes, S.J.; Cruden, A.R.; Arndt, N.; Saumur, B.M. The mineral system approach applied to magmatic Ni-Cu-PGE sulphide deposits. Ore Geol. Rev. 2016, 76, 296-316. [CrossRef] 
30. Hronsky, J.M.A. An Overview of Lithospheric through to Local Targeting. Presented at the 8th Fennoscandian Exploration and Mining Conference, Levi, Finland, 1-3 November 2011.

31. Hronsky, J.M.A. Self-Organised Critical Systems and Ore Formation: The Key to Spatial Targeting? Soc. Econ. Geol. Newsl. 2011, 84, 14-16.

32. Lottermoser, B.G. Rare-earth element mineralisation within the Mt. Weld carbonatite laterite, Western Australia. Lithos 1990, 24, 151-167. [CrossRef]

33. De Oliveira, S.M.B.; Imbernon, R.A.L. Weathering alteration and related REE concentration in the Catalão I carbonatite complex, central Brazil. J. South Am. Earth Sci. 1998, 1, 379-388. [CrossRef]

34. Chakhmouradian, A.R. High-field-strength elements in carbonatitic rocks: Geochemistry, crystal chemistry and significance for constraining the sources of carbonatites. Chem. Geol. 2006, 235, 138-160. [CrossRef]

35. Marks, M.A.W.; Markl, G. A global review on agpaitic rocks. Earth-Sci. Rev. 2017, 173, 229-258. [CrossRef]

36. Elliott, H.A.L.; Wall, F.; Chakhmouradian, A.R.; Siegfried, P.R.; Dahlgren, S.; Weatherley, S.; Finch, A.A.; Marks, M.A.W.; Dowman, E.; Deady, E. Fenites associated with carbonatite complexes: A review. Ore Geol. Rev. 2018, 93, 38-59. [CrossRef]

37. McCuaig, T.C.; Beresford, S.; Jon Hronsky, J.M.A. Translating the mineral systems approach into an effective exploration targeting system. Ore Geol. Rev. 2010, 38, 128-138. [CrossRef]

38. Geoscience Australia. Mineral Systems of Australia. Geoscience Australia, 2018. Available online: http: / / www.ga.gov.au/about/projects/resources/mineral-systems (accessed on 1 November 2018).

39. Hronsky, J.M.A. Optimising the Interface between Economic Geology Research and the Industry. In Proceedings of the AMIRA International's Exploration Managers Conference, Victoria, Australia, 23 March 2010.

40. Kreuzer, O.P.; Etheridge, M.P.; Guj, P.; McMahon, M.E.; Holden, D.J. Linking Mineral Deposit Models to Quantitative Risk Analysis and Decision-Making in Exploration. Econ. Geol. 2008, 103, 829-850. [CrossRef]

41. Orris, G.J.; Grauch, R.I. Rare Earth Element Mines, Deposits, and Occurrences; U.S. Geological Survey Open-File Report 02-189; U.S. Geological Survey: Reston, VA, USA, 2002.

42. Hoatson, D.M.; Jaireth, S.; Miezitis, Y. The major rare-earth-element deposits of Australia: Geological setting, exploration, and resources. Geosci. Aust. 2011, 204.

43. Knox-Robinson, C.M.; Wyborn, L.A.I. Towards a holistic exploration strategy: Using Geographic Information Systems as a tool to enhance exploration. Aust. J. Earth Sci. 1997, 44, 453-463. [CrossRef]

44. Goodenough, K.; Wall, F.; the HiTech AlkCarb Project Team. Developing exploration models for critical metals in alkaline complexes and carbonatites. Presented at the Mineral Deposits Studies Group 40th Annual Winter Meeting Conference, Bristol, UK, 19-21 December 2016.

45. Morgenstern, R.; Turnbull, R.E.; Hill, M.P.; Smillie, R.; Strong, D.T. The search for rare earth elements in New Zealand: A mineral systems and data discovery approach. In Proceedings of the 50th annual conference, New Zealand Branch of the Australasian Institute of Mining and Metallurgy, Christchurch, New Zealand, 10-13 September 2017.

46. Morgenstern, R.; Turnbull, R.E.; Hill, M.P.; Durance, P.M.J.; Rattenbury, M.S. Rare Earth Element Mineral Potential in New Zealand; GNS Science Consultancy Report; 2018/23; GNS Science: Lower Hutt, New Zealand, 2018; p. 211.

47. Skirrow, R.G.; Huston, D.L.; Mernagh, T.P.; Thorne, J.P.; Dulfer, H.; Senior, A.B. Critical Commodities for a High-Tech World: Australia's Potential to Supply Global Demand. Geoscience Australia, 2018. Available online: http:/ / www.ga.gov.au/data-pubs/data-and-publications-search/publications/criticalcommodities-for-a-high-tech-world (accessed on 4 December 2018).

48. Otis, R.M.; Schneidermann, N. A Process for Evaluating Exploration prospects. AAPG Bull. 1997, 81, 1087-1109.

49. Magoon, L.B.; Beaumont, E.A. Petroleum systems. In Exploring for Oil and Gas Traps: American Association of Petroleum Geologists Treatise of Petroleum Geology; Beaumont, E.A., Foster, N.H., Eds.; American Association of Petroleum Geologists: Tulsa, OK, USA, 1999; Volume 3, pp. 1-43. ISBN 9781629810744.

50. Magoon, L.B. The play that complements the petroleum system-A new exploration equation. Oil Gas J. 1995, 93, 85-87.

51. Royal Dutch Shell. Play Based Exploration: A Guide for AAPG's Imperial Barrel Award Participants. 2013. Available online: https:/ /iba.aapg.org/Portals/0/docs/iba/Play_Based_ExplorationGuide.pdf (accessed on 1 October 2018). 
52. Doust, H. Petroleum systems in Southeast Asian Tertiary basins. Bull. Geol. Soc. Malays. 2017, 64, 1-16. [CrossRef]

53. Magoon, L.B.; Schmoker, J.W. The total petroleum system-The natural fluid network that constrains the assessment unit. In U.S. Geological Survey World Petroleum Assessment; U.S. Geological Survey Digital Data Series 60; Description and Results; U.S. Geological Survey: Denver, CO, USA, 2000.

54. Lord, D.; Etheridge, M.A.; Willson, M.; Hall, G.; Uttley, P.J. Measuring exploration success: An alternative to the discovery-cost-per-ounce method of quantifying exploration success. Soc. Econ. Geol. Newsl. 2001, 45, 10-16.

55. Tyler, L.; Busuttil, S.; Des Rivieres, J.; McCormack, N.; McCuaig, T.C.; Terry, J. Value creation through exploration in BHP. 2017. Available online: https://www.ausimmbulletin.com/feature/value-creationexploration-bhp/ (accessed on 31 August 2018).

56. Rudnick, R.L.; Gao, S. Composition of the Continental Crust. In Treatise on Geochemistry; Rudnick, R.L., Holland, H.D., Turekian, K.K., Eds.; Elsevier: Oxford, UK, 2003; Volume 3, p. 659. ISBN 0-08-043751-6.

57. Swinden, S. (Swinden Geoscience Consultants Limited, Wolfville, NS, Canada). Personal communication, 2019.

58. Braunger, S.; Marks, M.A.W.; Walter, B.F.; Neubauer, R.; Reich, R.; Wenzel, T.; Parsapoor, A.; Markl, G. The Petrology of the Kaiserstuhl Volcanic Complex, SW Germany: The Importance of Metasomatized and Oxidized Lithospheric Mantle for Carbonatite Generation. J. Petrol. 2018, 59, 1731-1762. [CrossRef]

59. Linnaeus, C. Systema Naturae per Regna Tria Naturae, Secundum Classes, Ordines, Genera, Species, Cum Characteribus, Differentiis, Synonymis, Locis; Reformata, D., Ed.; Laurentius Salvius: Holmiae, Sweden, 1758; pp. 1-824.

60. Doust, H. The exploration play: What do we mean by it? AAPG Bull. 2010, 94, 1657-1672. [CrossRef]

61. Duncan, R.K.; Willett, G.C. Mount Weld Carbonatite. In Geology of the Mineral Deposits of Australia \& Papua New Guinea; Hughes, F.E., Ed.; The AusIMM: Melbourne, Australia, 1990.

62. Lynas Corp. Available online: https://www.lynascorp.com/Pages/Mt-Weld-Concentration-Plant.aspx (accessed on 1 September 2018).

63. Porter GeoConsultancy Pty Ltd. 2016. Available online: http://www.portergeo.com.au/database/mineinfo. asp? mineid $=$ mn770 (accessed on 1 September 2018).

64. Smith, M.P.; Moore, K.; Kavecsánszki, D.; Finch, A.A.; Kynicky, J.; Wall, F. From mantle to critical zone: A review of large and giant sized deposits of the rare earth elements. Geosci. Front. 2016, 7, 315-334. [CrossRef]

65. The EURARE Project. Available online: http://www.eurare.eu/ (accessed on 1 November 2018).

66. Mat Suli, L.; Ibrahim, W.H.B.W.; Aziz, B.A.; Deraman, M.R.; Ismail, N.A. A Review of Rare Earth Mineral Processing Technology. Chem. Eng. Res. Bull. 2017, 19, 20-35. [CrossRef]

67. Clement, C.R.; Reid, A.M. The origin of kimberlite pipes: An interpretation based on a synthesis of geological features displayed by southern African occurrences. In Kimberlites and Related Rocks; Ross, J., Jaques, A.L., Ferguson, J., Green, D.H., O’Reilly, S.Y., Danchin, R.V., Janse, A.J.A., Eds.; Geological Society of Australia: Sydney, Australia, 1989; Volume 14, pp. 632-646.

68. Porter GeoConsultancy Pty Ltd. Available online: http://www.portergeo.com.au/database/mineinfo.asp? mineid $=$ mn945 (accessed on 1 September 2018).

69. Jacob, J. Contextualized Risk Mitigation Based on Geological Proxies in Alluvial Diamond Mining Using Geostatistical Techniques. Ph.D. Thesis, University of the Witwatersrand, Johannesburg, South Africa, 2016.

70. Laniado, E.A. How We Find Diamond Sources: Kimberlite and Lamproite. Available online: https://www. ehudlaniado.com/home/index.php/news/entry/how-we-find-diamond-sources-kimberlite-and-lamproite (accessed on 1 September 2018).

71. De Beers, 2018. Available online: https://www.debeersgroup.com/en/news/company-news/companynews/world_s-most-advanced-diamond-exploration-vessel-officially-repo.html (accessed on 1 September 2018).

72. Debmarine Namibia. Available online: http://debmarinenamibia.com/main/ourhistory (accessed on 1 September 2018).

73. Namdeb. Available online: http://www.namdeb.com/ (accessed on 1 September 2018).

74. Pilet, S.; Baker, M.B.; Stolper, E.M. Metasomatized Lithosphere and the Origin of Alkaline Lavas. Science 2008, 320, 916-919. [CrossRef] [PubMed] 
75. Brauch, K.; Pohl, C.; Symons, G.; Tauchnitz, M. Deliverable D4.2 Paper on Instrument Tests and Best Practice for Carbonatites and Alkaline Rocks; Internal Paper of HiTech AlkCarb Project; Terratec Geophysical Services: Heitersheim, Germany, 2018; p. 478.

76. Jung, S.; Mezger, K.; Hauff, F.; Pack, A.; Hoernes, S. Petrogenesis of rift-related tephrites, phonolites and trachytes (Central European Volcanic Province, Rhön, FRG): Constraints from $\mathrm{Sr}, \mathrm{Nd}, \mathrm{Pb}$ and $\mathrm{O}$ isotopes. Chem. Geol. 2013, 354, 203-215. [CrossRef]

77. Baranyi, I.; Lippolt, H.J.; Todt, W. Kalium-Argon Altersbestimmungen an tertiären Vulkaniten des Oberrheingraben-Gebietes. II Der Alterstraverse vom Hegau nach Lothringen. Oberrhein. Geol. Abh 1976, 25, 41-62.

78. Walter, B.F.; Parsapoor, A.; Braunger, S.; Marks, M.A.W.; Wenzel, T.; Martin, M.; Markl, G. Pyrochlore as a monitor for magmatic and hydrothermal processes in carbonatites from the Kaiserstuhl volcanic complex (SW Germany). Chem. Geol. 2018, 498, 1-16. [CrossRef]

79. Barth, A.; Ritter, J.R.R.; Wenzel, F. Spatial variations of earthquake occurrence and coseismic deformation in the Upper Rhine Graben, Central Europe. Tectonophysics 2015, 651-652, 172-175. [CrossRef]

80. Franke, W.; Cocks, L.R.M.; Torsvik, T.H. The Palaeozoic Variscan oceans revisited. Gondwana Res. 2017, 48, 257-284. [CrossRef]

81. Beccaletto, L.; Capar, L.; Cruz-Mermy, D.; Rupf, I.; Nitsch, E.; Oliviero, G.; Elsass, P.; Perrin, A.; Stephane, M. The GeORG Project-Geological Potential of the Upper Rhine Graben-Situation, Goals and First Scientific Results; Abstractes 2010; 23ème Réunion des Science: Bordeaux, France, 2010.

82. Sissingh, W. Comparative Tertiary stratigraphy of the Rhine Graben, Bresse Graben and Molasse Basin: Correlation of Alpine foreland events. Tectonophysics 1998, 300, 249-284. [CrossRef]

83. Sissingh, W. Tertiary paleogeographic and tectonostratigraphic evolution of the Rhenish Triple Junction. Palaeogeogr. Palaeoclimatol. Palaeoecol. 2003, 196, 229-263. [CrossRef]

84. Schumacher, M.E. Upper Rhine Graben: Role of preexisting structure during rift evolution. Tectonics 2002, 21, 1006. [CrossRef]

85. Rotstein, Y.; Schaming, M. The Upper Rhine Graben (URG) revisited: Miocene transtension and transpression account for the observed first-order structures. Tectonics 2011, 30. [CrossRef]

86. Ziegler, P.A.; Cloetingh, S.; van Wees, J.-D. Dynamics of intra-plate compressional deformation: The Alpine foreland and other examples. Tectonophysics 1995, 252, 7-59. [CrossRef]

87. Rupf, I.; Nitsch, E. Das geologische Landesmodell von Baden-Württemberg: Datengrundlagen, technische Umsetzung und erste geologische Ergebnisse; Landesamt für Geologie, Rohstoffe und Bergbau Baden-Württemberg: Freiburg im Breisgau, Germany, 2008.

88. Geyer, O.F.; Gwinner, M.P. Geologie von Baden-Württemberg.—5., völlig neu bearbeitete Auflage; Schweizerbart'sche Verlagsbuchhandlung (Nägele u. Obermiller): Stuttgart, Germany, 2011; p. 627.

89. Wimmenauer, W.; Schreiner, A. Geologische Karte von Baden-Württemberg 1: 25,000; Kaiserstuhl. Landesamt für Geologie, Rohstoffe und Bergbau Baden-Württemberg: Freiburg, Germany, 2003.

90. Keller, J.; Brey, G.; Lorenz, V.; Sachs, P.; Schleicher, H. IAVCEI 1990: Pre-conference Excursion 2A: Volcanism and Petrology of the Upper Rhinegraben (Urach-Hegau-Kaiserstuhl). 1990; Unpublished field guide.

91. Wimmenauer, W. The alkaline province of Central Europe and France. In The Alkaline Rocks; Sorensen, H., Ed.; Wiley: London, UK, 1974; pp. 238-271.

92. Schleicher, H.; Keller, J.; Kramm, U. Isotope studies on alkaline volcanics and carbonatites from the Kaiserstuhl, Federal Republic of Germany. Lithos 1990, 26, 21-35. [CrossRef]

93. Egli, D.; Mosar, J.; Ibele, T.; Madritsch, H. The role of precursory structures on Tertiary deformation in the Black Forest-Hegau region. Int. J. Earth Sci. 2017, 106, 2297-2318. [CrossRef]

94. Lippolt, H.J.; Gentner, W.; Wimmenauer, W. Altersbestimmungen nach der Kalium-Argon-Methode an tertiären Eruptivgesteinen Südwestdeutschlands. Jahresh. Des Geol. Landesanst. Baden-Württemberg 1963, 6, 507-538.

95. Scotese, C.R. Plate Tectonic Maps and Continental Drift Animations by C. R. Scotese, PALEOMAP Project. Available online: www.scotese.com (accessed on 1 September 2018).

96. Mann, U.; Marks, M.; Markl, G. Influence of oxygen fugacity on mineral compositions in peralkaline melts: The Katzenbuckel volcano, Southwest Germany. Lithos 2006, 91, 262-285. [CrossRef] 
97. Hinsken, S.; Schmalholz, S.M.; Ziegler, P.A.; Wetzel, A. Thermo-Tectono-Stratigraphic Forward Modelling of the Upper Rhine Graben in reference to geometric balancing: Brittle crustal extension on a highly viscous mantle. Tectonophysics 2011, 509, 1-13. [CrossRef]

98. Lutz, M.; Cleintaur, M. Geological results of a hydrocarbon exploration campaign in the southern Upper Rhine Graben (Alsace Centrale, France). Bull. Appl. Geol. 1999, 4, 3-80. [CrossRef]

99. Walter, B.F.; Gerdes, A.; Kleinhanns, I.C.; Dunkl, I.; von Eynatten, H.; Kreissl, S.; Markl, G. The connection between hydrothermal fluids, mineralisation, tectonics and magmatism in a continental rift setting: Fluorite $\mathrm{Sm}-\mathrm{Nd}$ and hematite and carbonates U-Pb geochronology from the Rhinegraben in SW Germany. Geochim. Cosmochim. Acta 2018, 240, 11-42. [CrossRef]

100. Haase, K.H.; Beiera, C.; Regelousa, M.; Rapprich, V.; Rennoc, A. Spatial variability of source composition and petrogenesis in rift and rift flank alkaline lavas from the Eger Rift, Central Europe. Chem. Geol. 2017, 455, 304-314. [CrossRef]

101. Wilson, M.; Downes, H.; Cebriá, J.-M. Contrasting Fractionation Trends in Coexisting Continental Alkaline Magma Series; Cantal, Massif Central, France. J. Petrol. 1995, 36, 1729-1753. [CrossRef]

(C) 2019 by the authors. Licensee MDPI, Basel, Switzerland. This article is an open access article distributed under the terms and conditions of the Creative Commons Attribution (CC BY) license (http:/ / creativecommons.org/licenses/by/4.0/). 